\title{
UTJECAJ KONVENCIJE O PRAVIMA OSOBA S INVALIDITETOM NA KAZNENOPRAVNI INSTITUT NEUBROJIVOSTI ${ }^{1}$
}

UDK: $342-056.26$

$343.225-056.26$

Ur.: 11. rujna 2017.

Pr.: 6. studenoga 2017.

Izvorni znanstveni rad

\section{Sažetak}

U radu se analizira utjecaj Konvencije o pravima osoba s invaliditetom na kaznenopravni položaj jedne skupine osoba $s$ invaliditetom, $i$ to osoba $s$ duševnim smetnjama. Iako se u Konvenciji kaznena odgovornost izričito ne spominje, postoje tumačenja kako konvencijske odredbe zahtijevaju ukidanje kaznenopravnih instituta čija primjena dolazi u obzir zbog postojanja psihičkih smetnji okrivljenika, uz obrazloženje da su u suprotnosti s konvencijskim odredbama, posebice člancima 5. i 12.

Cilj je ovoga rada ispitati može li se odredba članka 12., koja uvodi bitne novine u području priznavanja poslovne sposobnosti osoba s duševnim smetnjama, proširiti i na njihovu kaznenu odgovornost te je li definicija neubrojivosti, čiji temelj čine duševne smetnje, u suprotnosti sa zahtjevima Konvencije, posebice odredbom članka 5. o jednakosti i nediskriminaciji.

Ključne riječi: Konvencija o pravima osoba s invaliditetom, osobe s duševnim smetnjama, neubrojivost, zabrana diskriminacije.

\section{UVOD}

Konvencija o pravima osoba s invaliditetom prvi je međunarodni dokument o ljudskim pravima usvojen u 21. stoljeću. ${ }^{2}$ U njezinoj izradi sudjelovali su predstavnici

* Dr. sc. Marissabell Škorić, izvanredna profesorica Pravnog fakulteta Sveučilišta u Rijeci; skoric@pravri.hr

1 Ovaj rad je sufinancirala Hrvatska zaklada za znanost projektom IP-11-2013-2287 „Legal Status and Real Position of People with Mental Difficulties - Interdisciplinary Approach and European Perspectives“ i Sveučilište u Rijeci potporama znanstvenim istraživanjima 13.08.1.3.02 „Interdisciplinarni pristup u istraživanju statusa osoba s duševnim smetnjama kroz prizmu konvencijskog prava“.

2 Konvencija o pravima osoba s invaliditetom usvojena je 13. prosinca 2006., a na snagu je stupila u svibnju 2008. (u daljnjem tekstu: Konvencija). Prema podatcima iz lipnja 2017. Konvenciju su ratificirale 174 države, među kojima i Republika Hrvatska (podatci o ratifikacijama dostupni 
niza država i nevladinih organizacija te veliki broj osoba s invaliditetom, uključujući osobe s duševnim smetnjama. Svi okupljeni imali su zajednički cilj osigurati da se osobe s invaliditetom prestanu tretirati kao objekti i da im se osigura uživanje ljudskih prava i temeljnih sloboda na jednakim osnovama kao i svim drugim ljudima. Ova Konvencija inzistiranjem na autonomiji osoba s invaliditetom, njihovom samoodređenju i slobodi izražavanja volje u potpunosti mijenja postojeću paradigmu koja se temelji na paternalističkom pristupu društva prema njima. ${ }^{3}$ Njezina bi primjena konačno trebala omogućiti da najveća manjinska skupina na svijetu bude vidljiva i prepoznata kao ravnopravan član društva. ${ }^{4}$

$\mathrm{U}$ ovom radu analizirat će se utjecaj Konvencije na jednu skupinu osoba $\mathrm{s}$ invaliditetom - osoba s duševnim smetnjama, i to u odnosu na njihov kaznenopravni položaj. Iako se u Konvenciji kaznena odgovornost izričito ne spominje, ${ }^{5}$ postoje mišljenja prema kojima konvencijske odredbe zahtijevaju od država stranaka ukidanje kaznenopravnih instituta čija primjena dolazi u obzir zbog postojanja određenih psihičkih smetnji okrivljenika. Ovaj zahtjev izvodi se, ponajprije, iz tumačenja odredbe članka 5. Konvencije koja regulira jednakost pred zakonom i zabranjuje bilo kakvu diskriminaciju na osnovi invaliditeta te odredbe članka 12. koja propisuje da osobe s invaliditetom imaju pravnu i poslovnu sposobnost na jednakoj osnovi kao i druge osobe u svim aspektima života. Odbor za prava osoba s invaliditetom tumačeći odredbu članka 12. potvrđuje da sve osobe s invaliditetom imaju poslovnu sposobnost te ističe da nedostatak mentalnih sposobnosti ne može biti opravdanje za njezino oduzimanje. ${ }^{6} \mathrm{Na}$ ovo se nadovezuje mišljenje Visokog povjerenika UN-a, koji je u svom izvješću iz 2009., izričito naveo da se članak 12. reflektira i na područje kaznenog prava. Stajalište je Visokog povjerenika da ova odredba zahtijeva ukidanje procesnog prava na obranu koje se temelji na mentalnim ili intelektualnim oštećenjima (engl. insanity defence) te uvođenje neutralne doktrine koja u sebi neće sadržavati procjenu navedenih oštećenja. ${ }^{7}$ Pojedini autori smatraju da se ovakvim tumačenjima

su na: http://www.ohchr.org/EN/HRBodies/ CRPD/Pages/CRPDIndex.aspx). Konvencija o pravima osoba s invaliditetom, Narodne novine - Međunarodni ugovori, 6/2007., 5/2008.

3 Grozdanić, V. (ur.), Komentar Zakona o zaštiti osoba s duševnim smetnjama, Pravni fakultet Sveučilišta u Rijeci, Rijeka, 2015., str. XVIII.

4 Prema podatcima Ujedinjenih naroda $10 \%$ svjetske populacije ili oko 650 milijuna ljudi živi s invaliditetom. V. United Nations, Fact sheet on Persons with Disabilities, dostupno na: http:// www.un.org/disabilities/ documents/toolaction/pwdfs. pdf.

5 Za potrebe ovog rada pod pojmom kaznene odgovornosti obuhvaćene su sve pretpostavke kažnjivosti, pa se kazneno odgovornim smatra počinitelj koji je počinio kazneno djelo te se u tom smislu kaznena odgovornost razlikuje od građanskopravne, prekršajne, moralne i druge odgovornosti. Više o pojmu kaznene odgovornosti v. Novoselec, P., Opći dio kaznenog prava, Pravni fakultet, Osijek, 2016., str. 204.

6 V. Committee on the Rights of Persons with Disabilities, General comment No. 1 (2014), Article 12: Equal recognition before the law, CRPD/C/GC/1, 19 May 2014., stavci 8. i 13. (u daljnjem tekstu: Opći komentar). Odbor za prava osoba s invaliditetom (u daljnjem tekstu: Odbor) tijelo je neovisnih stručnjaka koje prati provedbu Konvencije o pravima osoba s invaliditetom u državama strankama.

7 Annual report of the United Nations High Commissioner for human rights and Reports of the Office of the High Commissioner and the Secretary-General, Thematic Study by the Office of the United Nations High Commissioner for Human Rights on enhancing awareness and 
poručuje da je isključenje kaznene odgovornosti zbog neubrojivosti diskriminacija osoba s invaliditetom te traže ukidanje ovog instituta.

Prihvaćanje takvog tumačenja konvencijskih odredbi zahtijevalo bi bitne intervencije u kaznenopravnim sustavima gotovo svih država članica. Naime, u suvremenim kaznenim zakonodavstvima osobe s duševnim smetnjama uživaju zaseban status u odnosu na ostale počinitelje protupravnih djela, pa je novi pristup u priznavanju njihove pravne i poslovne sposobnosti nametnuo rasprave o potrebi redefiniranja njihova kaznenopravnog položaja. ${ }^{8}$ Ovo pitanje aktualno je i u zemljama kontinentalnoga pravnog kruga, koje razmatraju utjecaj psihičke bolesti na ponašanje pojedinca primarno u okviru krivnje kao jednog od elemenata u dogmatskoj konstrukciji kaznenog djela i u zemljama koje njeguju common law tradiciju, koje pitanje postojanja psihičke bolesti koja može dovesti do isključenja krivnje razmatraju u okviru procesnog prava na obranu (engl. insanity defence).

U radu će se razmotriti može li se domašaj članka 12. Konvencije koji primarno uređuje pitanje pravne i poslovne sposobnosti osoba s duševnim smetnjama protegnuti i na pitanje njihove kaznene odgovornosti te je li definicija instituta neubrojivosti, čiji temelj čine duševne smetnje, u suprotnosti sa zahtjevima Konvencije, posebice njezinim odredbama o jednakosti i nediskriminaciji.

\section{NAČELO JEDNAKOSTI I NEDISKRIMINACIJE - С̆LANAK 5. KONVENCIJE}

Načelo jednakosti jedno je od temeljnih načela suvremenog sustava zaštite ljudskih prava i sloboda. Odredbe o zabrani diskriminacije i/ili načelu jednakosti toliko su važne da su sadržane u svim temeljnim dokumentima o ljudskim pravima. ${ }^{9}$ Tako se i u članku 5. Konvencije propisuje da su sve osobe jednake pred zakonom te imaju jednako pravo, bez ikakve diskriminacije, na jednaku zaštitu i jednaku korist na temelju zakona. Stoga se države stranke obvezuju zabraniti bilo kakvu diskriminaciju na osnovi invaliditeta te jamčiti osobama s invaliditetom jednaku i djelotvornu zaštitu od diskriminacije po svim osnovama. ${ }^{10}$

understanding of the Convention on the Rights of Persons with Disabilities, A/HRC/10/48, 26 January 2009., str. 15.

8 Tako, primjerice Bach navodi: Central to legal capacity is ... to be held legally responsible and liable for one's actions in contract, tort, property and criminal law - i.e. to be one to whom legal obligations attach. Bach, M., The right to legal capacity under the UN Convention on the Rights of Persons with Disabilities: Key concepts and directions from law reform, Institute for Research and Development on Inclusion and Society (IRIS), Toronto, 2009., str. 3.

9 V. Opću deklaraciju o ljudskim pravima UN, Međunarodni pakt o građanskim i političkim pravima UN, Međunarodnu konvenciju o ukidanju svih oblika rasne diskriminacije UN, Konvenciju o ukidanju svih oblika diskriminacije žena UN, Europsku konvenciju o temeljnim pravima i slobodama i dr.

10 Prema Konvenciji diskriminacija na osnovi invaliditeta označava svako razlikovanje, isključivanje ili ograničavanje na osnovi invaliditeta koje ima svrhu ili učinak sprečavanja ili poništavanja priznavanja, uživanja ili korištenja svih ljudskih prava i temeljnih sloboda na političkom, ekonomskom, socijalnom, kulturnom, društvenom i svakom drugom području, na ravnopravnoj osnovi s drugima. Ona uključuje sve oblike diskriminacije, uključujući $i$ 
Međutim, unatoč općeprihvaćenosti načela jednakosti i zabrane diskriminacije, ne postoji suglasnost ni u filozofiji, ni u pravu, a niti javnog mijenja o tomu što ono zapravo znači. ${ }^{11}$ Klasično određenje načela jednakosti sadržano je u Aristotelovom poimanju jednakosti koje polazi od toga da jednake treba tretirati jednako, a nejednake nejednako. ${ }^{12}$ Bit antidiskriminacijskog prava sadržana je u neprihvatljivosti tretiranja jedne osobe ili skupine osoba na drukčiji, manje prihvatljiv način, u odnosu na drugu osobu ili skupine osoba u sličnim okolnostima. No, ovaj koncept jednakosti nije lišen konceptualnih izazova. Pitanje je kako ovu formalnu ili pravnu jednakost sadržanu $\mathrm{u}$ ideji da se prema pojedincima u jednakim situacijama mora postupati jednako, a s nejednakima nejednako, primijeniti u specifičnom kontekstu invaliditeta. Različito postupanje prema osobama može voditi diskriminaciji, no može biti i opravdano ako postoji odgovarajući razlog. Država može različito tretirati različite skupine zbog nekog njihovog svojstva koje ih čini različitim od ostalih, no mora za to predočiti prihvatljive razloge. Greer ističe kako je Europski sud za ljudska prava (u daljnjem tekstu: Europski sud) u nizu svojih odluka identificirao nekoliko smjernica za razgraničenje dopuštenog od nedopuštenog različitog postupanja u smislu članka 14 . Europske konvencije za zaštitu ljudskih prava i temeljnih sloboda. ${ }^{13}$ Prema praksi Europskog suda diskriminacija podrazumijeva različito postupanje prema osobama ili skupinama u sličnim situacijama, bez objektivnog i razumnog opravdanja. Objektivno i razumno opravdanje ne postoji ako razlika u postupanju ne postiže, tzv. legitiman cilj ili ako ne postoji razuman odnos razmjernosti između primijenjenih sredstava i ciljeva koje se težilo postići. ${ }^{14}$ Prema tomu, ako država dokaže da postoji legitimni cilj koji opravdava različitu praksu te da je učinak postupanja razmjeran ciljevima politike kojima se teži i ne pogađa pravičnu ravnotežu između zaštite općeg interesa i poštovanja temeljnih ljudskih prava, neće se raditi o diskriminaciji. ${ }^{15}$

Glavni konceptualni problem u kontekstu invalidnosti je taj što osobe s invaliditetom nisu u istom položaju kao ostali. Iako se pretjeruje sa stereotipima,

uskraćivanje razumne prilagodbe (v. čl. 4.).

11 Dworkin, R., Sovereign Virtue, the Theory and Practice of Equality, Cambridge, MA, Harvard University Press, 2000., Cooper, D., And You Can't Find Me Nowhere: Relocation Identity and Structure within Equality Jurisprudence, Journal of Law and Society, vol. 27., br. 2., 2000., str. 249-272., Phillips, A., Which Equalities Matter?, Malden, Blackwell, 1999.

12 Ovaj koncept jednakosti našao je svoje mjesto i u suvremenom međunarodnom pravu te je sadržan u mišljenju suca Tanake u slučaju Jugozapadne Afrike pred Međunarodnim sudom pravde u kojem ističe: Načelo jednakosti pred zakonom ne znači ... apsolutnu jednakost, naime jednako postupanje prema ljudima bez obzira na pojedinačne, konkretne okolnosti, nego znači ... relativnu jednakost, naime načelo postupati jednako prema onome što je jednako i nejednako prema onome što je nejednako... Postupati različito prema nejednakim stvarima u skladu s njihovom nejednakošću nije samo dopušteno nego se zahtijeva. Omejec, J., Konvencija za zaštitu ljudskih prava i temeljnih sloboda u praksi Europskog suda za ljudska prava, Strasbourški acquis, Novi informator, Zagreb, 2013., str. 878. V. South West Africa Case, ICJ Rep. 1966., 4.

13 Greer, S., The European Convention on Human Rights. Achievements, Problems and Prospects, Cambridge Studies in European Law and Policy, Cambridge University Press, Cambridge, 2006.

14 V. presudu u predmetu Andrejeva protiv Latvije, 18. veljače 2009., st. 81.

15 V. presudu u predmetu Abdulaziz, Cabales i Balkandali protiv Ujedinjenog Kraljevstva, 28. svibnja 1985., st. 72. 
razlike između osoba s invaliditetom i onih koje to nisu, često su stvarne. ${ }^{16}$ Polazeći od ovoga stava, veliki broj autora smatra neprihvatljivim mišljenje prema kojem je svako pozivanje na psihičko oštećenje pri donošenju odluke koja utječe na neko pravo osobe diskriminacija. Kayess i French ističu da nepriznavanje stvarnih razlika vodi samo prema površnoj jednakosti i kritiziraju tumačenje članka 12. Konvencije koje vodi potpunom negiranju ograničenja vezanih uz kognitivna oštećenja. ${ }^{17}$ Dawson navodi kako se ne može smatrati diskriminacijom ako se, primjerice, osobi koja ima akutne paranoidne deluzije prema svojim susjedima ne izda dozvola za nošenje oružja, uz obrazloženje da navedena bolest djeluje na njezinu sposobnost da se tim oružjem služi odgovorno. Takva odluka ne temelji se na pukom postojanju dijagnoze mentalne bolesti, već na razlici između sposobnosti te osobe i drugih osoba da sigurno izvrši određenu radnju. Ignoriranje takvih oštećenja u funkcioniranju osobe moglo bi ozbiljno ugroziti njezine i tuđe interese. Dawson bitnim smatra odrediti svojstvo na kojem se temelji različito postupanje prema osobama. Ne negirajući izvjesne probleme u preciznom procjenjivanju unutrašnjeg funkcioniranja i stanja ljudskog uma, ističe kako oštećenje mentalnih funkcija može biti razmatrano kao relevantno za određene odluke. ${ }^{18}$ Caivano smatra da načelo nediskriminacije sadržano u Konvenciji treba biti tumačeno tako da puko postojanje intelektualnih ili psihosocijalnih oštećenja, samo po sebi, ne može biti dovoljan dokaz o tomu da osoba nije sposobna sama donositi odluke. Prema njemu moraju postojati drugi dokazi koji upućuju na to da je osobi potrebna pomoć kako bi donijela odgovarajuću odluku. ${ }^{19}$ Callaghan i Ryan smatraju kako inzistiranje na stajalištu da biti autonoman znači da se u svakom slučaju mora poštovati izrečena volja, bez bilo kakvog propitivanja sposobnosti osobe da ju izrazi, otvara niz praktičkih i etičkih pitanja za koja nemamo odgovor. Primjerice, što ako se izražena volja temelji na potpuno pogrešnom tumačenju relevantnih činjenica ili ne shvaćanju ozbiljnosti posljedica koje mogu proizaći iz tako izražene volje. ${ }^{20}$ I Barlett smatra da mentalno stanje može biti u određenim slučajevima važno za prikladan odgovor društva te kako činjenica da je psihičko stanje osobe često u povijesti bilo iskorišteno na krajnje neprimjerene načine, nužno ne znači da je uvijek bila riječ o diskriminaciji. $^{21}$

Iz navedenoga se može zaključiti kako neki od autora opravdano razlikuju, $\mathrm{s}$ jedne strane, puko izdvajanje osoba na temelju njihova invaliditeta, te s druge,

16 Arnardóttir, O. M.; Quinn, G., The UN Convention on the Rights of Persons with Disabilities, European and Scandinavian Perspectives, Martinus Nijhoff Publishers, Netherlands, 2009., str. $\mathrm{xx}$.

17 Kayess, R.; French, P., Out of darkness into light? Introducing the Convention on the Rights of Persons with disabilities, Human Rights Law Review, vol. 8., br. 1., 2008., str. 7.

18 Dawson, J., A realistic approach to assessing mental health laws' compliance with the UNCRPD, International Journal of Law and Psychiatry, vol. 40., 2015., str. 73.

19 Caivano, N., Conceptualizing Capacity: Interpreting Canada's Qualified Ratification of Article 12 of the UN Disability Rights Convention, Western Journal of Legal Studies, vol. 4., br. 1., 2014., str. 19.

20 Callaghan, S. M.; Ryan C., Is there a future for involuntary treatment in Right-based Mental Health Law, Psychiatry, Psychology and Law, vol. 21., br. 5., 2014., str. 748, 755.

21 Barlett, P., The United Nations Convention on the Rights of Persons with Disabilities and Mental Health Law, Modern Law Review, vol. 75., br. 5., 2012., str. 763-764. 
oduzimanje nekoga prava osobi na temelju njezine nesposobnosti da izvrši određenu radnju te ne prihvaćaju tumačenje Odbora koji u potpunosti negira bilo kakvu mogućnost pozivanja na mentalne sposobnosti pojedinca pri donošenju odluke o njegovoj poslovnoj sposobnosti. ${ }^{22}$

\section{PRAVNA I POSLOVNA SPOSOBNOST- ČLANAK 12. KONVENCIJE}

Unatoč postojanja niza međunarodnih dokumenta o zaštiti temeljnih ljudskih prava koji se odnose na sve ljude, u stvarnosti su osobe s duševnim smetnjama često bile tretirane kao zasebna skupina za koju su vrijedila drukčija pravila. Tijekom cijele ljudske povijesti bile su arbitrarno zatvarane, prisilno liječene te izložene nečovječnom i ponižavajućem postupanju. Kao jedan od ključnih razloga za takvo stanje pokazalo se to što je osobama s duševnim smetnjama često bila ograničena ili oduzeta poslovna sposobnost, a bez poslovne sposobnosti većina ostalih prava koja im se jamče, ostaju mrtvo slovo na papiru. Iako je tijekom povijesti i nekim drugim kategorijama osoba bila oduzeta poslovna sposobnost kao primjerice, ženama, danas se to pitanje u odnosu na njih više ne postavlja te se čini da su kognitivna oštećenja jedina preostala karakteristika na temelju koje se u suvremenim pravnim poredcima opravdava oduzimanje poslovne sposobnosti. ${ }^{23}$ Naime, u većini pravnih sustava poslovna sposobnost stječe se s navršenih 18 godina života, no istodobno je propisano da se osobama s psihosocijalnim i/ili intelektualnim oštećenjima poslovna sposobnost pod određenim uvjetima može oduzeti ili ograničiti. ${ }^{24} \mathrm{U}$ tom slučaju osoba ne može samostalno donositi odluke i pretvorena je u objekt isključen iz gotovo svih sfera života. Kako je upravo uživanje poslovne sposobnosti temeljna pretpostavka osobne slobode te samostalnosti i neovisnosti, ne čudi zašto se najvažnijom odredbom u Konvenciji smatra članak 12. Pojedini autori ovu odredbu nazivaju the beating heart of the Convention i njezinu implementaciju označavaju kao poseban prioritet. ${ }^{25}$

Tijekom pregovora oko teksta članka 12. vodile su se dugotrajne rasprave koje su se nastavile i nakon stupanja Konvencije na snagu. Jedan od najvećih izazova za države stranke postao je usklađivanje nacionalnog zakonodavstva s konvencijskim zahtjevima. Pitanja koja su izazvala najviše rasprave bila su kako definirati pojam legal capacity i može li se on oduzeti ili ograničiti osobi s invaliditetom, odnosno

22 Detaljnije o tumačenju čl. 12. od strane Odbora v. infra, poglavlje 3.

23 Flynn, E.; Arstein-Kerslake, A., The Support Model of Legal Capacity: Fact, Fiction, or Fantasy?, Berkley Journal of International Law, vol. 23., br. 1., 2014., str. 125.

24 Osobe s psihičkim problemima mogu biti potpuno ili djelomično lišene poslovne sposobnosti u gotovo svim državama Europske unije. Za detalje v. Legal capacity of persons with intellectual disabilities and persons with mental health problems, European union agency for fundamental rights, Luxembourg: Publications Office of the European Union, 2013, dostupno na: http:// fra.europa.eu/sites/default/files/legal-capacity-intellectual-disabilities-mental-health-problems. pdf, str. 31.

25 Commissioner for Human Rights, Who gets to decide?, Rights to legal capacity for persons with intellectual and psychosocial disabilities, Council of Europe, Strasbourg, 20 February 2012., CommDH/IssuePaper(2012)2., str. 14. 
može li i dalje egzistirati model zamjenskog odlučivanja. ${ }^{26}$ Opće prihvaćena definicija pojma legal capacity ne postoji, a države različito definiraju njegov sadržaj. U nekim je pravnim sustavima ovaj pojam ograničen isključivo na sposobnost osobe biti nositelj prava i obveza (engl. legal standing ili capacity to hold rights and duties). Drugi pravni sustavi idu korak dalje i u njega uključuju i sposobnost osobe da poduzima radnje unutar pravnog sustava (engl. legal agency ili capacity to exercise rights and duties). ${ }^{27}$ Hoće li se prihvatiti njegovo uže ili šire tumačenje iznimno je važno upravo za osobe s duševnim smetnjama. Naime, pravna sposobnost ove kategorije osoba nije sporna, no njihova poslovna sposobnost, odnosno sposobnost da donose pravno relevantne odluke često je osporavana. Stoga samo pojam legal capacity koji uključuje i poslovnu i pravnu sposobnost, čini pojedinca subjektom prava. Tijekom pregovora bilo je pokušaja da se njegovo značenje ograniči isključivo na sposobnost da osoba bude nositelj prava i obveza, no takvi prijedlozi na kraju nisu ušli u konačan tekst Konvencije. ${ }^{28}$ Iako su nakon usvajanja konačnoga teksta prijepori oko sadržaja ovog pojma i dalje ostali, ${ }^{29}$ danas je nedvojbeno da pojam legal capacity iz članka 12. Konvencije treba shvatiti u njegovu najširem smislu. ${ }^{30}$ Ovakvo tumačenje potvrdio je i Odbor koji je u Općem komentaru uz članak 12. istaknuo da legal capacity includes the capacity to be both a holder of rights and an actor under the law. ${ }^{31}$

Drugo sporno pitanje tijekom pregovora bilo je može li se pod određenim uvjetima poslovna sposobnost oduzeti ili ograničiti. Jedan dio država polazio je od pretpostavke da postoje iznimni slučajevi kada osoba ne može izvršavati poslovnu sposobnost. Smatrali su da takvi slučajevi trebaju biti regulirani u Konvenciji i zalagali se za uvođenje nekog od oblika skrbništva. S druge strane, postojali su oni koji su smatrali da je sustav skrbništva i zamjenskog odlučivanja u povijesti donio toliko nepravde

26 Više vidi u: Schulze, M., Understanding The UN Convention On The Rights Of Persons with Disabilities, A Handbook on the Human Rights of Persons with Disabilities, Handicap International, September, 2009., str. 60-65.

27 V. Opći komentar, st. 12. i 13.

28 Jedan od prijedloga tijekom pregovora bio je da se uz čl. 12. st. 2. usvoji bilješka koja je propisivala da se značenje legal capacity u tri od šest službenih jezika UN-a (arapskom, kineskom i ruskom) ograničava isključivo na sposobnost da osoba bude nositelj prava i obveza. Sadržaj ove bilješke ograničio bi značenje legal capacity isključio na capacity for rights i tako doveo u pitanje ostvarenje svrhe Konvencije te otvorio niz pravnih pitanja. Stoga ne čude ogromni napori uloženi u njezino brisanje od strane udruga civilnog društva, kao i pojedinih država koje su zahtijevale da pojam legal capacity ima jedinstveno tumačenje u svim državama strankama. Caivano, N., op. cit., str. 1-2.

29 Tako je i prvi službeni prijevod Konvencije na hrvatski jezik pod pojmom legal capacity podrazumijevao samo pravnu sposobnost (v. Narodne novine - Međunarodni ugovori, 6/2007.), a naknadnim ispravkom obuhvaćena je i poslovna sposobnost (v. Narodne novine Međunarodni ugovori, 5/2008.).

30 Minkowitz, T., The United Nations Convention on the Rights of Persons with Disabilities and the right to be free from non-consensual psychiatric interventions, Syracuse Journal of International Law and Commerce, vol. 34, br. 2., 2007., str. 411. Isto tvrde i Barlett, P., op. cit., str. 764. i Callaghan, S. M.; Ryan C., An evolving revolution: Evaluating Australia's compliance with the Convention on the Rights of Persons with Disabilities in Mental Health Law, UNSW Law Journal, vol. 39., br. 2., 2016., str. 602.

31 Opći komentar, st. 12. i 14. 
osobama s duševnim smetnjama da stvari sada treba promatrati iz drukčijeg kuta. ${ }^{32} \mathrm{Iz}$ konačnoga teksta odredbe članka 12. proizlazi da su tvorci Konvencije prepoznali da postoje razlike među ljudima i da pojedinac može imati određene specifičnosti koje ga razlikuju od drugih. Bili su svjesni da odluka o tomu je li netko sposoban samostalno donijeti odluku nije uvijek jednostavna i da određeno oštećenje može, u većoj ili manjoj mjeri, utjecati na ovu sposobnost. No, za razliku od dosadašnje općeprihvaćene prakse koja je u ovakvim slučajevima rješavala problem na način da bi osobi imenovala skrbnika koji je umjesto nje donosio odluke, Konvencija nameće obvezu državama poduzimanja odgovarajućih mjera kojima će se osigurati podrška i pomoći osobi da sama donese odluku, odnosno koje će omogućiti da se i u tim slučajevima poštuju njezina prava, volja i sklonosti. ${ }^{33}$ Time se omogućava da osobe s invaliditetom uživaju poslovnu sposobnost na jednakoj osnovi kao i svi drugi u svim aspektima života $\mathrm{i}$ da formalnopravno nikada ne izgube autonomiju. Ovakav koncept uvelike odstupa od većine europskih zakonodavstava koja primarno uređuju uvjete i postupak za oduzimanje, odnosno ograničavanje poslovne sposobnost. Pritom koriste različite modele, no većinom prihvaćaju, tzv. funkcionalni pristup oduzimanja (ograničavanja) poslovne sposobnosti koji se temelji na procjeni kognitivnih sposobnosti pojedinca, tj. njegovoj sposobnosti da shvati prirodu i posljedice određene odluke. ${ }^{34}$ Postojanje dijagnoze nije dovoljna osnova da bi se nekoga lišilo poslovne sposobnosti, no ono je često povod za procjenu određenih mentalnih funkcija osobe, ponajprije njezine sposobnosti da razumije prirodu i posljedicu svojih odluka (tzv. mentalni kapacitet ili kapacitet za odlučivanje). Upravo procjena mentalnoga kapaciteta ima ključnu ulogu pri donošenju odluke o lišavanju poslovne sposobnosti. ${ }^{35}$ Odluke i izbori onih koji imaju kapacitet za odlučivanje poštuju se, dok oni za koje se utvrdi da ne raspolažu s njim, gube poslovnu sposobnost, što njihovu volju čini pravno irelevantnom. ${ }^{36}$

32 Iako je institut skrbništva uveden radi zaštite osoba pod skrbništvo, niz istraživanja ukazuje na njegove brojne nedostatke. Guardianship has been overused and abused in the medical, as well as other, contexts, including at the most extreme level to place persons with intellectual disabilities in psychiatric institutions. This is inappropriate medically and socially, and is inconsistent with the rights of persons with intellectual disabilities to health, autonomy, participation, non-discrimination and social inclusion. Report of the Special Rapporteur on the right of everyone to the enjoyment of the highest attainable standard of physical and mental health, Paul Hunt, Report to the Sixty-first session of the Commission on Human Rights, 11 February 2005, E/CN.4/2005/51, st. 79.

33 V. čl. 12. st. 4. Konvencije.

34 Tri su općepoznata modela oduzimanja poslovne sposobnosti. Prema, tzv. statusnom pristupu (engl. status approach) za oduzimanje poslovne sposobnosti dovoljno je postojanje određenog oblika i stupnja oštećenja, bez obzira na stvarne sposobnosti osobe. Pristup ishoda (engl. outcome approach) usmjeren je na procjenu razumnosti (reasonableness) odluke koju pojedinac sam donosi, dok se funkcionalni pristup (engl. functional approach) temelji na procjeni mentalnih sposobnosti osobe da razumije prirodu i posljedice svojih odluka.

35 Detaljno o mentalnom kapacitetu i njegovoj procjeni v. Štrkalj Ivezić, S., Procjena kapaciteta za odlučivanje kao ključan faktor u donošenju odluke za lišavanje poslovne sposobnosti, u: Poslovna sposobnost i skrbništvo - raskorak između Konvencije o pravima osoba s invaliditetom i prakse, Zbornik radova sa stručnog skupa, Pravobraniteljica za osobe s invaliditetom, Zagreb, 2012., str. 65-74.

36 Ovakav pristup prihvaćen je u većini suvremenih zakonodavstava unatoč tomu što niz autora 
U svom tumačenju članka 12. Odbor ističe kako je funkcionalni model za procjenu poslovne sposobnosti manjkav, i to iz dva razloga. Prvo, jer diskriminira osobe s psihičkim oštećenjima koje će prije negoli ostale osobe pasti na testu koji uključuje procjenu mentalnih sposobnosti i drugo, jer pretpostavlja da smo sposobni točno procijeniti unutarnje stanje ljudskog uma. Odbor bilo kakvo pozivanje na mentalne sposobnosti pri donošenju odluke o oduzimanju poslovne sposobnosti ili bilo koje druge odluke koja utječe na neko pravo, smatra diskriminacijom osobe na osnovi njezina mentalnog oštećenja i suprotno zahtjevima Konvencije. Tako, prema mišljenju Odbora, procjena mentalnoga kapaciteta ne može biti osnova za oduzimanje poslovne sposobnosti, jer taj koncept nije objektivan, ne temelji se na znanstveno utemeljenim kriterijima i krajnje je kontroverzan. Pritom Odbor ne osporava mogućnost da na strani osobe postoje određena oštećenja, no prema njegovom mišljenju ona nikako ne mogu biti osnova za oduzimanje poslovne sposobnosti, već su ona osnova za nametanje obveze državama strankama da toj osobi osiguraju podršku kako bi mogla realizirati svoju poslovnu sposobnost. No, ni ta podrška, ističe Odbor, ne smije zavisiti o procjeni mentalnih sposobnosti, nego je nužno usvojiti neke druge pokazatelje koji nisu tako diskriminirajući. ${ }^{37}$ Ovakvo tumačenje članka 12. Odbora, predmet je brojnih rasprava u znanstvenoj i stručnoj literaturi. Pritom se svi slažu da Konvencija zahtijeva redefiniranje pojma legal capacity u odnosu na osobe s invaliditetom. No, ne postoji jedinstveno stajalište o tomu treba li prihvatiti šire tumačenje Odbora koje u biti ne ostavlja prostor za ograničenje poslovne sposobnosti na temelju mentalnih sposobnosti ${ }^{38}$ ili je dostatna uža interpretacija članka 12. koja zahtijeva pomak od zamjenskog prema potpomognutom odlučivanju.

U biti širokog tumačenja članka 12. ideja je da osobe s mentalnim oštećenjima imaju, kao i svi drugi, pravo na vlastite izbore i na vlastite pogreške te da im se to pravo treba priznati u svim područjima života. To nameće pitanje treba li se takvo široko priznavanje poslovne sposobnosti u kontekstu donošenja osobnih odluka odraziti i na proširenje njihove kaznene odgovornosti. ${ }^{39}$ Visoki povjerenik UN-a smatra da odgovor na ovo pitanje treba biti pozitivan te zauzima stajalište da priznavanje pravne i poslovne sposobnosti osoba $\mathrm{s}$ invaliditetom zahtijeva redefiniranje određenih kaznenopravnih instituta koji uključuju procjenu psihičkih ili intelektualnih oštećenja. ${ }^{40}$ Prema njegovom mišljenju prepoznavanje legal capacity

ukazuje na složenost i kompleksnost postupka procjene nečijih mentalnih sposobnosti, ističući kako za takvu procjenu ne postoji gold standard. Amer, A. B., Informed Consent and Adult Psychiatry, Oman Medical Journal, vol. 28., br. 4., 2013., str. 230., Banner, N. F.; Szmukler, G., „Radical interpretation “ and the Assessment of decision-making capacity, Journal of Applied Philosophy, vol. 30., br. 4., 2013., str. 382.

37 Opći komentar, st. 9., 13., 14., 15., 21. i 29 (i).

38 Neki od autora ovo tumačenje smatraju radikalnim. V. Dawson, J., op. cit., str. 70-79.

39 Craigie, J., A Fine Balance: Reconsidering Patient Autonomy in Light of the UN Convention on the Rights of Persons with Disabilities, Bioethics, vol. 29., br. 6., 2015., str. 7.

$40 \mathrm{U}$ tumačenju čl. 12. Visoki povjerenik izričito navodi whether the existence of disability is a direct or indirect ground for a declaration of legal incapacity, legislation of this kind conflicts with the recognatuion of legal capacity of persons with disabilities enshrined in art. 12 para 2. Annual report of the United Nations High Commissioner for human rights and Reports of the Office of the High Commissioner and the Secretary-General, Thematic Study by the Office 
osoba s invaliditetom u području kaznenog prava, zahtijeva ... abolishing a defence based on the negation of criminal responsibility because of the existence of a mental or intellectual disability. Instead disability-neutral doctrines on the subjective element of the crime should be applied, which take into consideration the situation of the individual defendant. ${ }^{41}$ I pojedini autori slažu se da takvo, široko priznavanje prava na autonomiju povlači za sobom i jednakost u poimanju kaznene odgovornosti. Kako bi se to izjednačavanje dosljedno provelo u praksi potrebno je u kaznenom pravu ukinuti sve institute koji uključuju procjenu mentalnih sposobnosti. Minkowitz tvrdi da institut neubrojivosti koji se temelji na psihičkim oštećenjima krši temeljna načela Konvencije na štetu osoba koje imaju takva oštećenja. ${ }^{42}$ Negiranje kaznene odgovornosti zbog postojanja neubrojivosti predstavlja diskriminaciju osoba $\mathrm{s}$ invaliditetom i povrjeđuje njihovo pravo na jednakost pred zakonom. Minkowitz tvrdi da obrana neubrojivošću koja se temelji na mentalnom oštećenju pretpostavlja da su osobe s psihosocijalnim oštećenjima as less than moral equals with other persons. ${ }^{43}$ Prema ovoj autorici poštovanje načela nediskriminacije zahtijeva prihvaćanje, tzv. univerzalnog modela sposobnosti, prema kojem se svim osobama koje izraze svoju volju mora priznati pravni učinak takvih odluka, bez propitivanja njihove mentalne sposobnosti da to učine. ${ }^{44}$ Slobogin se također slaže sa zaključkom da Konvencija traži od država stranaka da ne izdvajaju osobe s mentalnim oštećenjima u zasebnu skupinu smatrajući takvu praksu stigmatizirajućom i štetnom jer širi mit da je riječ o posebno opasnim osobama. On predlaže ukidanje obrane neubrojivošću kao zasebne obrane i omogućavanje osobama s psihičkim poremećajima korištenje svih vrsta obrane koje inače stoje na raspolaganju osobama koje nemaju takve poremećaje (tzv. integrationist approach) ${ }^{45}$ Drugim riječima, okolnosti koje su sada konceptualizirane kao psihička oštećenja i razmatraju se u okviru obrane neubrojivošću, i dalje će se uzimati u obzir, samo što će se procijenjvati u okviru subjektivnih elemenata kaznenog djela. Time osobe s duševnim smetnjama neće biti izdvojena skupina za koju vrijede posebna pravila. Ovakav stav podržava i niz nevladinih organizacija koje se zalažu za prava osoba s duševnim smetnjama. Tako World Network of Users and Survivors of Psychiatry smatra da institut neubrojivosti treba ukinuti, odnosno zamijeniti nekim

of the United Nations High Commissioner for Human Rights on enhancing awareness and understanding of the Convention on the Rights of Persons with Disabilities, A/HRC/10/48, 26 January 2009, stavak 45.

41 UN High Commissioner for Human Rights, Annual Report, Thematic Study on CRPD, A/ HRC/10/48, 26 January 2009, stavak 47.

42 Minkowitz, T., Rethinking criminal responsibility from a critical disability perspective: The abolition of insanity/incapacity acquittals and unfitness to plead, and beyond, Griffith Law Review, vol. 23., br. 3., 2014., str. 434-466.

43 Minkowitz, T., Submission to Committee on the Rights of Persons with Disabilities on the Draft General Comment on Article 12, January 22, 2014., str. 3.

44 Ibid., str. 1.

45 Slobogin, C., Eliminating mental disability as a legal criterion in deprivation of liberty cases: the impact of the Convention on the rights of persons with disabilities on the insanity defense, civil commitment, and competency law, International Journal of Law and Psychiatry, vol. 40., 2015., str. 38-42. 
drugim mjerama koje u sebi ne sadrže diskriminaciju na temelju invaliditeta. ${ }^{46}$

Razmatrajući pitanje treba li se članak 12. proširiti i na pitanje kaznene odgovornosti osoba s duševnim smetnjama, potrebno je prethodno ukazati na sličnosti, ali i bitne razlike koje postoje između procjene poslovne sposobnosti ili sposobnosti donošenja odluka i procjene neubrojivosti. Njihova temeljna zajednička karakteristika je ta da se radi o područjima u kojima se isprepliću psihijatrija i pravo. I u procjeni sposobnosti donošenja odluka i prilikom utvrđivanja neubrojivosti razmatra se postojanje psihičke bolesti ili poremećaja te njezin utjecaj na sposobnost osobe da donese određenu odluku (npr. podvrći se određenom medicinskim tretmanu), odnosno na intelektualne i voljne sposobnosti okrivljenika u kontekstu počinjenja određenoga kaznenog (protupravnog) djela. Pritom u obje ove evaluacije važnu ulogu imaju psihijatri. Daljnja zajednička karakteristika je ta da obje procjene uključuju normativnu (vrijednosnu) ocjenu o određenom djelu, odnosno izboru osobe te da njihovo utvrđivanje povlači za sobom neposredne pravne posljedice. Tako procjena da na strani osobe ne postoji sposobnost odlučivanja ima odlučujuću ulogu pri donošenju odluke o lišenju poslovne sposobnosti, dok utvrđenje da se osoba kaznenopravnim normama nije suprotstavila svjesno i voljno vodi isključenju njezine krivnje, a time i kažnjavanja za počinjeno (protupravno) djelo. ${ }^{47}$

Unatoč navedenim sličnostima, između procjene sposobnosti donošenja odluka i procjene neubrojivosti postoje i bitne razlike. Pitanje sposobnosti donošenja odluka pitanje je autonomije čovjeka, dok je pitanje neubrojivosti pitanje njegove kaznene odgovornosti. Iako postoji poveznica između sadržaja autonomije i sadržaja kaznene odgovornosti, kontekst u kojem se autonomija i kaznena odgovornost propituju bitno je različit, kao i posljedice koje za osobu iz njega mogu proizaći. Povod za procjenu neubrojivosti povreda je pravnih normi, odnosno postojanje protupravnog djela koje je kažnjivo, dok je povod za procjenu sposobnosti donošenja odluka izbor između različitih mogućnosti čija je zajednička karakteristika da su dopuštene. Kod procjene sposobnosti donošenja odluke primarno je riječ o tomu je li osoba sposobna donijeti odluku koja je u njezinu najboljem interesu (primjerice, dati pristanak na određeni medicinski postupak). S druge strane, procjena neubrojivosti nije motivirana medicinskim, niti bilo kojim drugim interesom osobe o kojoj se radi, već proizlazi iz kaznenopravnog sustava određene države koji propisuje kažnjavanje onih koji počine kaznena djela, kao i mogućnost njihove ekskulpacije pod određenim uvjetima. Pored toga, procjena sposobnosti donošenja odluka odnosi se na aktualni trenutak, odnosno bližu budućnost, dok se procjena neubrojivosti vrši u odnosu na određeni trenutak u bližoj ili daljnjoj prošlosti, što zacijelo predstavlja veći izazov za sve koji u njoj sudjeluju.

Doslovno i beziznimno prihvaćanje širokog tumačenja članka 12. u sferi kaznenog prava, značilo bi da se moraju napustiti neka od temeljnih načela modernih

46 V. World Network of Users and Survivors of Psychiatry, dostupno na: http://wnusp.rafus.dk/ mental-health-and-prisons-a-usersurvivor-perspective-and-why-it-is-needed.html.

47 Meynen, G., Legal Insanity: Explorations in Psychiatry, Law, and Ethics, Springer, Heidelberg, 2016., str. 87-91., Parmigiani, G.; Mandarelly, G.; Meynen, G. et al., Free will, neuroscience, and choice: towards a decisional capacity model for insanity defense evaluations, Rivista di psichiatria, vol. 52., br. 1., 2017., str. 12-13. 
kaznenopravnih sustava. Ukidanje instituta neubrojivosti i priznavanje poslovne sposobnosti kako to zahtijevaju pojedini autori pozivajući se na tumačenje Odbora, zapravo otvara mogućnost kažnjavanja osoba s duševnim smetnjama. To zacijelo nije bio cilj koji su autori Konvencije željeli ostvariti regulirajući poslovnu sposobnost $\mathrm{u}$ članku 12., a dvojbena je i ispravnost zaključka da je tumačenje članka 12. od strane Odbora imalo ovakav cilj. Naime, i Odbor ističe kako poslovna sposobnost ima posebnu važnost za osobe s invaliditetom kada one donose odluke o svom zdravlju, edukaciji i poslu ispuštajući bilo kakvo povezivanje članka 12. s kaznenom odgovornošću. ${ }^{48}$ Pored toga, nejasno je kako bi se koncept potpomognutog odlučivanja koji čini ključni sadržaj članka 12. mogao primijeniti u kontekstu kaznene odgovornosti osoba s duševnim smetnjama.

\section{INSTITUT NEUBROJIVOSTI}

Suvremeno kazneno zakonodavstvo europskih država temelji se na načelu krivnje, nulla poena sine culpa, koje je osnova individualne odgovornosti za počinjeno djelo i legitimacija za izricanje kazne. ${ }^{49}$ Ono polazi od toga da se pojedincu mogu uračunati samo one radnje koje su rezultat njegovog izbora i da kaznu zaslužuje samo ona osoba koja je prema svojim individualnim mogućnostima bila sposobna shvatiti pravila i djelovati u skladu s njima. Osobe koje nemaju ove kapacitete, jer zbog svoje bolesti nisu sposobne shvatiti značenje i posljedice svojih postupaka, smatraju se neubrojivima. No, nije oduvijek bilo tako. Na početku svog razvoja kazneno pravo bilo je utemeljeno na objektivnoj odgovornosti i kao takvo je bilo puno jednostavnije. Pojedinac je odgovarao zbog prouzročene posljedice i nije se smatralo važnim je li bio sposoban djelovati u skladu s pravilima ili ne. Izricanje kazne bilo je svedeno na neku vrstu matematike, jer je za određeno djelo bila propisana apsolutno određena kazna, pri čemu je bilo irelevantno je li osoba, npr. ukrala nešto iz pohlepe ili zbog gladi. Suvremeno je kazneno pravo pravednije jer je uspostavilo kriterije za razgraničenje slučajnih štetnih djela čovjeka od onih kojima ostvaruje kaznena djela za koja može biti kažnjen. Istodobno, ono je i puno teže jer traži da uđemo u unutrašnji svijet čovjeka i utvrdimo kakav je subjektivni odnos imao prema počinjenom djelu.

U modernom kaznenom pravu psihičko zdravlje počinitelja izravno utječe na njegovu krivnju. No, već su i starogrčki filozofi prepoznali da pojedine osobe zbog svoga psihičkog stanja zahtijevaju poseban tretman. Tako su Platon i Aristotel u svojim djelima upozorili na nepravednost, besmislenost i društvenu neprihvatljivost

48 Opći komentar, st. 8.

49 U pojedinim državama načelo krivnje izdignuto je na rang ustavnog načela, no i u državama u kojima načelo krivnje nije izričito propisano u najvišem pravnom aktu, priznat mu je ustavnopravni status. Tako je njemački federalni Ustavni sud (Bundesverfassungsgericht) u nekoliko svojih odluka istakao da je kazneno pravo utemeljeno na načelu krivnje koje pretpostavlja odgovornost pojedinca koji sam određuje svoje ponašanje i koji na temelju svoje slobodne volje odlučuje hoće li činiti dobro ili loše. Hörnle, T., Guilt and Choice in Criminal Law Theory - A Critical Assessment, Bergen Journal of Criminal Law and Criminal Justice, vol. 4., br. 1., 2016., str. 1-2. 
kažnjavanja počinitelja s duševnim smetnjama. ${ }^{50}$ Nametanje kaznene odgovornosti pojedincima koji nisu bili sposobni shvatiti značenje određenog djela i ponašati se $u$ skladu s tim, smatralo se onda, kao i danas, neprihvatljivim. Upravo je smisao instituta neubrojivosti isključiti krivnju za onu kategoriju počinitelja čije je delinkventno ponašanje uvjetovano psihopatološkim čimbenicima koji djeluju na njihove mentalne i voljne sposobnosti na način da ih onemogućuju da svoje ponašanje usklade $\mathrm{s}$ važećom pravnom regulativom.

Općeprihvaćeno je da se moralno i pravno osoba može okriviti za svoje ponašanje samo ako je mogla djelovati drukčije. Upravo u činjenici što je počinjenje kaznenog djela rezultat slobodnog odlučivanja čovjeka koji je mogao drukčije postupiti negoli je postupio, nalazi se moralna i pravna legitimacija kazne. No, odgovoriti na pitanje je li, i ako je, u kolikoj mjeri, pojedinac imao mogućnost izbora i je li odgovoran za svoje postupke nije nimalo lagana zadaća. U pozadini ovih dvojbi nalazi se pitanje postoji li sloboda volje (liber arbitrium). Iako filozofske, etičke, teološke i pravne rasprave oko definicije ovog pojma traju stoljećima i još uvijek im se ne nazire kraj, sloboda volje zasigurno je jedan od najčešće razmatranih i korištenih koncepata kako bi se razjasnila i opravdala neubrojivost kao institut kaznenog prava. Pritom se teorije koje su pitanje neubrojivosti razmatrale u okviru slobode volje, mogu podijeliti na one koje zastupaju indeterminizam i one koje stoje na determinističkim postavkama. Indeterminizam polazi od toga da čovjek nije podvrgnut kauzalnim zakonima i da je njegova volja neovisna o bilo kojem utjecaju, pa se počinitelja kažnjava zato što je kao slobodno biće mogao uskladiti svoje ponašanje sa zahtjevima pravnog poretka, no nije to učinio. Determinizam, pak, polazi od suprotne teze smatrajući da je sloboda volje samo privid, da je čovjek podvrgnut općim kauzalnim zakonima i da je određen u svojim odlukama i postupcima. ${ }^{51}$

Preispitujući stavove o legitimnosti kažnjavanja samo u slučajevima ako je osoba mogla odučiti drukčije Hörnle ističe kako sloboda volje kao koncept može biti dopuštena u nekom pravnom kontekstu, no mora biti napuštena u kaznenom pravu zbog niza manjkavosti. Hörnle zahtijeva preispitivanje prevladavajućeg objašnjenja zašto je kod neubrojivih osoba isključena krivnja, smatrajući nezadovoljavajućim tumačenje da one nisu mogle odlučiti drukčije. To nije kriterij koji omogućava razlikovanje između osoba koje imaju psihičku bolest i onih koje nemaju, jer prema

50 Njihove ideje bile su ispred vremena u kojem su živjeli i nisu mogle biti pretočene u kaznenopravne odredbe sve dok se nisu počeli uvažavati subjektivni elementi u kaznenom pravu. To se prvi put dogodilo u starorimskom pravnom sustavu koji je propisao posebne odredbe za počinitelje kaznenih djela s duševnim smetnjama i prepoznao kao relevantne subjektivne elemente kaznenog djela. Tako se u Justinijanovoj kodifikaciji mogu prepoznati začetci zasebnog kaznenopravnog položaja osoba s duševnim smetnjama temeljenog na stavu da osobe s duševnim smetnjama nemaju volju za počinjenje kaznenog djela, zbog čega je njihova odgovornost isključena. O povijesnom razvoju pravnog položaja neubrojivih počinitelja protupravnih djela v. Đurđević, Z., Pravni položaj počinitelja kaznenih djela s duševnim smetnjama, Hrvatsko udruženje za kaznene znanosti i praksu, Zagreb, 2002., str. 7-113., Grozdanić, V., Tragovi razvoja posebnog statusa neuračunljivog delinkventa u povijesti krivičnog prava starog i srednjeg vijeka, Zbornik Pravnog fakulteta u Rijeci, god. 9., 1988., str. 37-52.

51 Novoselec, P., op. cit., str. 199-200. 
ovoj autorici ni psihički zdrava osoba nije mogla drukčije odlučiti. ${ }^{52}$ Ključna za evaluaciju neubrojivosti je nemogućnost osobe da se uključi u smislenu komunikaciju o tomu što je učinila. U tomu leži objašnjenje zašto psihički bolesne osobe (kao i djecu) ne bi trebalo kažnjavati. Kazneno pravo treba shvatiti kao dijalog između optuženog i onog koji ga poziva na odgovornost za ono što je učinio. Da bi sudjelovao u tomu, optuženiku su nužne komunikacijske vještine u širem smislu. To znači da treba posjedovati kognitivne sposobnosti tako da može slušati i razgovarati, razumjeti riječi i složene rečenice te odgovarati na razumljiv način, kao i da mora imati sposobnost temeljnog razumijevanja stvarnosti i apstraktnih normativnih pojmova kao što su, npr. „prava drugih“. Vrlo mlade osobe, osobe s većim intelektualnim oštećenjima te osobe s iznimno iskrivljenim pogledom na stvarnost nemaju te vještine. ${ }^{53}$

Danas u teoriji kaznenog prava prevladava stajalište da je kazneno pravo indiferentno prema pitanju slobode kao „metafizičkom“ i da ono mora poći od onoga što je nepobitno. ${ }^{54}$ Ovakav stav čini se prihvatljiv, s obzirom na to da do sada svi pokušaji da se slobodi volje pristupi iz znanstvenoga kuta nisu urodili plodom. ${ }^{55}$ Ako rasprava o nekom pojmu traje stoljećima, kao što to jest slučaj s raspravom o slobodi volje, onda možemo zaključiti kako svi donekle imaju pravo, no nitko nije u potpunosti odgovorio na to pitanje. No, iako se formalno negira problem slobode, čini se da kazneno pravo ipak nije ravnodušno prema ovom problemu koji je i dalje ostao skriven unutar indiferentističkih teorija ${ }^{56}$ Ove teorije slobodu volje ne smatraju relevantnom za rješavanje pitanja neubrojivosti, nego odgovor na to pitanje vežu uz nepostojanje intelektualnih i voluntarističkih komponenti čovjeka, odnosno njegovu sposobnost da shvati značenje svog postupanja i vlada svojom voljom.

Bez obzira na postojanje teorija koje daju različite odgovore na pitanje što opravdava postojanje instituta neubrojivosti u kaznenom pravu, suvremena kaznena zakonodavstva jednoglasno polaze od pravila da svaki čovjek ima dovoljan stupanj psihičkog razvoja koji ga čini sposobnim rasuđivati i odlučivati i prihvaćaju pretpostavku prema kojoj se svi počinitelji smatraju ubrojivima. No, ta je pretpostavka oboriva i u zakonima se definira pojam neubrojivosti. Iako ne postoji jedinstvena definicija neubrojivosti te se uređenje pravnog položaja neubrojivih počinitelja protupravnih djela smatra jednim od većih izazova za kaznenopravnu znanost i praksu, ovaj je institut općeprihvaćen u kaznenopravnim sustavima suvremenih europskih država, kao i u većini američkih saveznih država. ${ }^{57}$

52 Hörnle brani pristup koji pripada široj grupi kompatibilističkih teorija koje pokušavaju pomiriti determinizam i slobodu volje. Kompatibilistički pristup prihvaća da su svi ljudski postupci determinirani, ali pritom ne poriče postojanje osobne slobode. Detaljnije v. Berčić, B., Filozofija, Ibis grafika, Zagreb, 2012.

53 Hörnle, T., op. cit., str. 17.

54 Novoselec, P., op. cit., str. 199.

55 Detaljan kritički osvrt na korištenje koncepta slobode volje u kaznenom pravu v. Hörnle, T., op. cit., str. 4-5.

56 Novoselec, P., op. cit., str. 199.

57 Četiri američke države, Idaho, Kansas, Montana i Utah ukinule su obranu neubrojivošću. Montana je obranu neubrojivošću ukinula još 1979. Iz istraživanja provedenog u razdoblju od 1976. do 1979. te od 1980. do 1985. proizlazi kako je nakon ukidanja obrane neubrojivošću uvelike porastao broj okrivljenika koji su bili nesposobni za suđenje (raspravna nesposobnost). 


\subsection{Kratki komparativni prikaz definicije neubrojivosti}

Među nacionalnim kaznenim zakonodavstvima postoje bitne razlike u reguliranju instituta neubrojivosti. Te se razlike očituju već u položaju neubrojivosti u strukturi kaznenog djela. Tako zemlje kontinentalnog pravnog kruga neubrojivost preispituju u okviru krivnje, dok je u common law sustavima ona dio procesnog prava na obranu. ${ }^{58}$ Razlike se dalje nastavljaju u različitim definicijama neubrojivosti, ovisno o tomu koju su od tri poznate metode utvrđivanja neubrojivosti države prihvatile: biološku, psihološku ili biološko-psihološku (mješovitu) metodu. ${ }^{59}$

Biološka metoda sastoji se isključivo u utvrđivanju postojanja nekog abnormalnog psihičkog stanja. Utjecaj tog stanja na psihičke funkcije pojedinca smatra se irelevantnim i stoga se ne razmatra. Prema tomu, za postojanje neubrojivosti dostatno je utvrditi da je osoba tempore criminis imala neku duševnu bolest, dok je pitanje je li, i ako je, u kolikoj mjeri ta bolest utjecala na njezine intelektualne i voljne sposobnosti, pravno irelevantno. Prema biološkoj metodi postojanje određene bolesti automatski isključuje ubrojivost. ${ }^{60} \mathrm{U}$ suvremenom kaznenom zakonodavstvu ova metoda nije naišla na šire prihvaćanje, a Norveška je jedna od rijetkih zemlja koja ju je usvojila. ${ }^{61}$ Stoga se definicija neubrojivosti iz § 20. norveškoga Kaznenog zakona bitno razlikuje od definicije neubrojivosti u drugim kaznenim zakonodavstvima. ${ }^{62}$ U § 20. Kaznenog zakona kao osnove neubrojivosti navode se psihoza, mentalna nesposobnost i nesvjesnost, dok se ne razmatra utjecaj tih stanja na intelektualne $\mathrm{i}$ voljne sposobnosti okrivljenika. ${ }^{63}$

Zaključak je bio kako se moralo pronaći alternativno rješenje za pojedince $s$ duševnim smetnjama koji krše pravne norme, a nisu sposobni za krivnju. Packer, I. K., Evaluation of criminal responsibility, Oxford University Press, Oxford, 2009., str. 8., 167-172.

58 Struktura kaznenog djela u common law sustavima bitno odstupa od suvremenoga kontinentalnog modela europskih država. Iako se u literaturi često ističe kako anglosaksonsko pravo svoju konstrukciju kaznene odgovornosti gradi na dva temeljna elementa: actus reus i mens rea, pri čemu actus reus obuhvaća vanjske elemente kaznenog djela, dok se mens rea odnosi na unutarnje, subjektivne sastojke kaznenog djela, ispravnijom se čini definicija Lanhama koji ističe kako crime is made up of three ingredients, actus reus, mens rea and (a negative element) absence of a valid defence. Lanham, D., Larsonneur Revisited, Criminal Law Review, 1976.

59 Detaljnije v. Grozdanić, V.; Škorić, M.; Martinović, I., Kazneno pravo, opći dio, Pravni fakultet Sveučilišta u Rijeci, Rijeka, 2013., str. 137-138.

60 Biološka metoda bila je usvojena, primjerice, u francuskom Kaznenom zakoniku iz 1810. (čl. 64.).

61 New Hampshire jedina je američka država koja je prihvatila biološku metodu. U toj se državi primjenjuje Durhamovo pravilo prema kojem se optuženi ne smatra kazneno odgovornim ako je djelo za koje je optužen rezultat psihičke bolesti ili oštećenja. Carlan, P.; Nored, L. S.; Downey, R. A., An Introduction to Criminal Law, Jones and Bartlett Publishers, Inc., United States, 2001., str. 150-151.

62 Novi norveški Kazneni zakon, stupio je na snagu 1. listopada 2015. V. Act 2015-06-19-65 on the Entry into Force of the Criminal Code of 2005 (Lov om ikraftsetting av straffeloven 2005).

63 Pojam „nesvjesnosti“ (engl. unconscious; state of automatism) odnosi se na ekstremno rijetke slučajeve gdje počinitelj djeluje bez da percipira svoju okolinu, a često je praćeno gubitkom pamćenja. To može biti posljedica, npr. mjesečarenja ili epileptičnog napada. Gröning, L.; Rieber-Mohn, G. F., NOU 2014:10 - Proposal for New Rules Regarding Criminal Insanity and 
Definicija neubrojivosti bila je predmet brojnih rasprava posljednjih nekoliko godina u Norveškoj. Slučaj Breivik potaknuo je široku diskusiju o kaznenopravnom statusu okrivljenika s psihičkim poremećajima, poglavito o odredbama kojima je reguliran institut neubrojivosti. ${ }^{64}$ Naime, prema odjeljku 44. norveškoga Kaznenog zakona koji je bio na snazi u trenutku počinjenja djela, počinitelj koji je tempore crimins bio psihotičan nije kazneno odgovoran. ${ }^{65}$ Ta je odredba, u suštini, izjednačavala neubrojivost i psihozu te nije zahtijevala dokazivanje uzročne veze između psihotičnog stanja okrivljenika i njegovih intelektualnih i/ili voljnih sposobnosti. Pravna definicija pojma $p$ sihoze bila je identična njegovu medicinskom značenju, uz dodatak da je pravo zahtijevalo da se tempore criminis psihoza mora očitovati kroz relevantne simptome karakteristične za ovu bolest. Drugim riječima, osoba koja pati od navedene bolesti, ali je pod medicinskim tretmanom i stoga nije (aktivno) psihotična ne bi potpadala pod odredbu odjeljka 44. Slučaj Breivik potaknuo je preispitivanje potrebe za promjenom ove odredbe te je osnovan poseban odbor čiji su članovi bili pravnici, liječnici, psiholozi, filozofi i etičari. Jedno od glavnih pitanja koje su trebali razmotriti bilo je treba li odustati od medicinskog modela utvrđivanja neubrojivosti i prihvatiti mješoviti model koji će tražiti utvrđivanje uzročnosti između osnova neubrojivosti i njihovog utjecaja na ponašanje okrivljenika. Na prvi pogled činilo se da bi takvo pravilo bolje identificiralo one koje se ne bi trebalo smatrati kazneno odgovornima. Također, bila bi jasnija granica između uloge vještaka koji bi primarno procjenjivali mentalno stanje okrivljenika i uloge suda koji bi odlučivao je li utjecaj tog stanja dovoljno bitan da isključi kaznenu odgovornost. Ipak je na kraju Odbor zaključio kako bi primjena mješovite metode utvrđivanja neubrojivosti prouzročila velike poteškoće i nejasnoće, budući da ne postoji sigurna osnova za odlučujuću procjenu o tomu je li dijagnosticirani psihički poremećaj utjecao na počinjenje djela ili ne. Prema mišljenju Odbora, psihijatrija nema nikakvu znanstvenu osnovu niti osnovu oko koje bi svi bili suglasni, za utvrđivanje postojanja uzročne veze između psihotičnog poremećaja i počinjenog djela, zbog čega su i stručnjaci prisiljeni oslanjati se na labave pretpostavke. Stoga je teško pretpostaviti da bi primjena mješovite metode utvrđivanja neubrojivosti doprinijela značajnijoj ulozi sudova prilikom konačne procjene o postojanju neubrojivosti. ${ }^{66} \mathrm{Na}$ kraju je Odbor zaključio kako se preciznost i točnost najbolje mogu postići u okviru odredbe utemeljene na medicinskom modelu.

Related Issues, Norway post-22 July, Bergen Journal of Criminal Law and Criminal Justice, vol. 3., br. 1., 2015., str. 112.

64 Breivik je parkirao kamionet-bombu u Oslu 22. srpnja 2011. godine ispred ureda norveškog premijera te je u eksploziji bombe poginulo osam osoba. Nakon toga otišao je na otok Utoya, gdje je ubio još 69 osoba. Zbog počinjenja kaznenog djela terorizma (\$147), prouzročenja eksplozije sa smrtnom posljedicom (§148) i ubojstava (§233) osuđen je na kaznu zatvora u trajanju od 21 godine.

65 Section 44. Sub-section 1.: A person who was psychotic or unconsciousness at the time of committing the act shall not be liable to a penalty. Sub-section 2.: The some applies to a person who at the time of committing the act was mentally retarded to a high degree. The General Civil Penal Code with subsequent amendments, the latest made by Act of 21 December 2005 No. 131, Norwegian Ministry of Justice Legislation Department, 2006., dostupno na: app.uio.no/ ub/ ujur/oversatte-lover/.../lov-19020522-010-eng.pdf.

66 Gröning, L., Rieber-Mohn, G., op. cit., str. 114. 
No, predložio je i određene izmjene odredbe odjeljka 44. prema kojima bi samo počinitelj koje je u vrijeme počinjenja djela imao izraženi intenzitet psihotičnih simptoma trebao biti izuzet od kaznenopravne odgovornosti. Odbor je, također, predložio da osnovama neubrojivosti budu obuhvaćena i ostala stanja koja se mogu izjednačiti s psihozama. Tako je osnove za isključenje kaznenopravne odgovornosti proširio i na druge ozbiljne mentalne poremećaje zbog kojih osoba ima poremećaj mišljenja, smanjenu sposobnost djelovanja ili poremećaj percepcije stvarnosti, ako su oni izraženi u istoj mjeri i intenzitetu kao kod osobe koja je psihotična. Odbor je predložio i da osnova neubrojivosti, pored mentalne retardacije, budu i slična oštećenja. Razlog za ovo proširenje bilo je shvaćanje da postoje pojedinci koji nisu mentalno retardirani od rođenja, ali kod kojih se kasnije u životu jave takva oštećenja koja smanjuju njihove kognitivne i druge funkcije na razinu osobe s visokim stupnjem mentalne retardacije. To se posebno odnosi na slučajeve ozljeda mozga zbog, npr. različitih nesreća. ${ }^{67}$

Unatoč raspravi oko definicije neubrojivosti i detaljno obrazloženim prijedlozima za njezinu izmjenu, u novom norveškom Kaznenom zakonu iz 2015. godine ipak nisu uvedene bitnije promjene. ${ }^{68}$ Kao glavna prednost postojećeg rješenja ističe se to što ono ograničava isključenje krivnje, u prvom redu, na slučajeve postojanja psihoze koji su i inače najčešće razmatrana osnova koja vodi neubrojivosti. No, ova je odredba izložena i nizu kritika. Glavni prigovor odnosi se na činjenice da ekskulpacija osoba od kaznene odgovornosti samo na temelju postojanja dijagnoze psihoze upućuje na pogrešan zaključak kako su takve osobe općenito nesposobne donositi bilo kakve odluke, čime se negira njihova autonomija i sprječava njihovo uključivanje u društveni život. ${ }^{69}$ Osobe koje imaju dijagnozu psihoze mogu biti i jesu sposobne preuzeti odgovornost za odluke koje donose. Zato puko postojanje bolesti u vrijeme počinjenja djela ne bi smjelo biti dovoljan razlog za utvrđivanje njihove neubrojivosti. Pored toga, kao daljnja kritika ističe se kako je ovakva definicija neubrojivosti preuska jer njome nisu obuhvaćena sva stanja koja mogu dovesti do isključenja intelektualnih $\mathrm{i}$ voljnih sposobnosti osobe.

U nizozemskom kaznenom zakonodavstvu također nisu propisani pravni standardi za utvrđivanje neubrojivosti. U dijelu 39. Kaznenog zakona navodi se $d a$ osoba koja počini djelo za koje ne može biti odgovorna zbog psihičkog oštećenja ili psihičke bolesti nije kazneno odgovorna. Ovom odredbom propisano je da postojanje psihičke bolesti ili oštećenja može isključiti kaznenu odgovornost, no nije određeno koji to uvjeti, pored psihičke bolesti, trebaju biti ispunjeni kako bi došlo do toga. No, iako je u zakonskoj definiciji prihvaćena biološka metoda, u praksi se, zapravo,

67 Prijedlog teksta Odbora glasio je: A person whom the court deems to have been psychotic at the time of committing the act, or in a condition which, due to reduced functioning, disordered thinking, or otherwise to the inability to comprehend their relationship with their surroundings, must be equated with psychosis, is free from criminal responsibility. The same applies to a person who acted under a severe disorder of consciousness. Gröning, L., Rieber-Mohn, G. F., op. cit., str. 113.

68 Jacobsen, J.; Hallgren Sandvik, V., An Outline of the New Norwegian Criminal Code, Bergen Journal of Criminal Law and Criminal Justice, vol. 3., br. 2., 2015., str. 177.

69 Meynen, G., op. cit., str. 73. 
primjenjuje mješovita metoda. Naime, psihijatar koji vještači okrivljenika u svom nalazu treba odgovoriti na određena pitanja, između ostalog, je li poremećaj utjecao na ponašanje okrivljenika i ako je, na koji način i u kojem opsegu te koji zaključak iz toga proizlazi u pogledu njegove kaznene odgovornosti. Iz forme ovih pitanja proizlazi kako je za postojanje neubrojivosti relevantan utjecaj mentalnog oštećenja ili poremećaja na okrivljenika, no i dalje nije jasno koja će to vrsta utjecaja rezultirati isključenjem kaznene odgovornosti. Vještaci su ti koji razvijaju svoje vlastite argumente o neubrojivosti okrivljenika pri čemu koriste kriterije koje oni smatraju relevantnima za kaznenu odgovornost u konkretnom slučaju, umjesto da vrednuju ponašanje okrivljenika u svjetlu pravnih standarda. Konačna evaluacija okrivljenika na kraju je rezultat onoga što je utvrdio psihijatar u konkretnom slučaju te njegovih kriterija za donošenje zaključka o neubrojivosti okrivljenika. Nedvojbeno je da u ovakvom sustavu vještakov vlastiti pogled o utjecaju mentalnog poremećaja na ponašanje okrivljenika ima veliku ulogu. Povrh toga, vještaci daju i izričiti savjet sudu o stupnju okrivljenikove kaznene odgovornosti. Sud, doduše, ne mora prihvatiti savjet, no u velikom broju slučajeva to čini. Zbog vrlo velike slobode koju vještaci imaju pri tumačenju neubrojivosti, ovakvo rješenje izloženo je nizu kritika. ${ }^{70}$

Druga metoda za utvrđivanje neubrojivosti psihološka je metoda. Prema ovoj metodi osoba je neubrojiva ako tempore criminis nije mogla shvatiti značenje svog djela ili vladati svojom voljom, bez obzira na to koja su nenormalna psihička stanja to prouzročila. Psihološka metoda utvrđivanja neubrojivosti nije do sada pronašla širu primjenu u praksi uz obrazloženje kako njezina primjena dovodi u pitanje pravnu sigurnost. Naime, polazi se od stajališta kako je forenzička psihopatologija do sada izgradila određena načela o utvrđivanju uzročne veze između pojedinih duševnih smetnji i ubrojivosti pa se propisivanjem bioloških osnova olakšava utvrđivanje neubrojivosti i jamči poštovanje dostignuća psihopatologije. ${ }^{71}$ Pored toga, njome se doprinosi i objektivnosti odluke o neubrojivosti osobe jer utvrđenje da osoba pati od, npr. shizofrenije može dodatno potvrditi pouzdanost zaključka da nije znala da radi nešto nedopušteno. ${ }^{72} \mathrm{No}$, unatoč tomu što ova metoda nije naišla na šire prihvaćanje u nacionalnim kaznenim zakonodavstvima, postoje autori koji zastupaju stav da, umjesto prevladavajućeg koncepta temeljenog na postojanju psihičkog poremećaja, temelj isključenja kaznene odgovornosti treba biti vezan isključivo uz intelektualne sposobnosti osobe. ${ }^{73}$

Švicarska je jedna od rijetkih država koja je u svom kaznenom zakonodavstvu prihvatila psihološku metodu. ${ }^{74}$ Ovo je rješenje uvedeno 2007. godine, nakon što su na

70 Ibid., str. 37-40.

71 Novoselec, P., op. cit., str. 209.

72 Morse, S. J., Mental disorder and criminal law, Journal of Criminal Law and Criminology, vol. 101., br. 3., 2011., str. 895-896., Meynen, G., op. cit., str. 156.

73 Matthews, S., Failed agency and the insanity defence, International Journal of Law and Psychiatry, vol. 27., br. 5., 2004., str. 413-424., Vincent, N. A., Responsibility, Dysfunction and Capacity, Neuroethics, vol. 1., br. 3., 2008., str. 200-201.

74 Prijedlog za uvođenjem psihološke metode postojao je tijekom rasprave oko donošenja njemačkoga Kaznenog zakonika 1975. godine, no odbačen je uz obrazloženje da bi takva metoda dovela u pitanje pravnu sigurnost. Novoselec, P., op. cit., str. 209. 
snagu stupile izmjene i dopune općega dijela Kaznenog zakona. Prije usvajanja novog modela i u švicarskom kaznenom zakonodavstvu bila je prihvaćena mješovita metoda utvrđivanja neubrojivosti. No, kako je bila izložena nizu kritika, tijekom rasprave oko izmjena i dopuna Kaznenog zakona, definiciji pojma neubrojivosti posvećena je osobita pažnja. ${ }^{75}$ Prvotni je prijedlog bio da se, načelno, i dalje zadrži mješovita metoda utvrđivanja neubrojivosti, a da se kao osnove neubrojivosti navedu samo teške psihičke smetnje. ${ }^{76}$ No, poteškoće koje su nastale oko pokušaja da se ovaj pojam detaljnije odredi dovele su do iznenađujućeg rješenja, odnosno do brisanja ovog pojma iz Kaznenog zakona. U aktualnom članku 19. Kaznenog zakona izostavljeno je navođenje osnova neubrojivosti te se neubrojiva osoba definira kao ona koja je u trenutku djela bila nesposobna spoznati nedopuštenost (wrong) svog djela ili djelovati u skladu s tom spoznajom. ${ }^{77}$ Nova definicija tako slijedi jednu čisto psihološku metodu koja za utvrđivanje neubrojivosti traži samo isključenje sposobnosti shvaćanja i/ ili odlučivanja. No, treba istaknuti da bez obzira na to što osnove neubrojivosti nisu navedene u zakonskom tekstu, u praksi su one i dalje relevantne. Detaljnijim određenjem mogućih razloga za isključenje sposobnosti za krivnju bavi se, prije svega, forenzička psihijatrija, a kao osnova koja može dovesti do isključenja ubrojivosti i dalje je u prvom planu psihoza. ${ }^{78}$ Dakle, iako psihička bolest nije formalni kriterij za utvrđivanje neubrojivosti, objašnjenje vještaka o tomu zašto su kod okrivljenika bile isključene intelektualne i/ili voljne sposobnosti i dalje se veže uz postojanje određene psihičke bolesti ili poremećaja.

Konačno, treća je metoda utvrđivanja neubrojivosti biološko-psihološka (mješovita) metoda. ${ }^{79}$ Ova je metoda prihvaćena u većini angloameričkih i europskih država, pa tako i u Hrvatskoj. ${ }^{80}$ Za razliku od prethodno navedenih metoda, mješovita metoda uključuje dva kriterija, biološki i psihološki, pa se smatra da su njezini zaključci pouzdaniji u odnosu na preostale dvije metode koje koriste samo jedan kriterij za utvrđivanje neubrojivosti. Prema mješovitoj metodi najprije se mora utvrditi postojanje određenog biološkog stanja, a nakon toga treba istražiti njegov utjecaj na

75 Graf, M.; Dittmann, V., Psychopathic Disorder and the Criminal Law in Switzerland, u: Felthous, A., Sass, H. (ur.), International Handbook on Psychopathic Disorders and the Law, vol. II., John Wiley and Sons, Ltd., 2008., str. 230.

76 Prije navedenih izmjena i dopuna kao osnove neubrojivosti, švicarski Kazneni zakon navodio je mentalnu bolest, idiotizam ili ozbiljno oštećenje mentalnih sposobnosti. U odjeljku 10. navodi se da: any person suffering from a mental disease, idiocy or serious impairment of his mental faculties, who at the time of committing the act is incapable of appreciating the unlawful nature of his act or acting in accordance with the appreciation may not be punished.

77 Schweizerisches Strafgesetzbuch, art. 19. Schuldunfähigkeit und verminderte Schuldfähigkeit (1) War der Täter zur Zeit der Tat nicht fähig, das Unrecht seiner Tat einzusehen oder gemäss dieser Einsicht zu handeln, so ist er nicht strafbar.

78 Stratenwerth, G.; Wohlers, W., Schweizerisches Strafgesetzbuch, Handkommentar, Stämpfli Verlag, Bern, 2013., str. 43-44.

79 Naziv „biološko-psihološka metoda“ u praksi trpi brojne kritike, no s obzirom na to da se neki drugi naziv koji bi bolje odražavao sadržaj ove metode do sada nije ustalio, i dalje se koristi postojeći naziv. Novoselec, P., op. cit., str. 210.

80 V. čl. 24. st. 2. Kaznenog zakona Republike Hrvatske, Narodne novine, 125/2011., 144/2012., 56/2015., 61/2015., 101/2017. 
sposobnost počinitelja shvaćanja značenja svog postupanja i na njegovu mogućnost vladanja svojom voljom. U odredbi članka 24. stavka 2. Kaznenog zakona Republike Hrvatske propisane su četiri biopsihološke osnove neubrojivosti, i to duševna bolest, privremena duševna poremećenost, nedovoljni duševni razvitak i druge teže duševne smetnje. Posljednju osnovu hrvatski zakonodavac uveo je Kaznenim zakonom iz 1997. godine, po uzoru na njemačko i austrijsko rješenje. Nadopuna se smatrala nužnom zbog novih spoznaja u općoj i forenzičkoj psihijatriji koje su pokazale da postoje psihički abnormalna stanja koja se ne mogu podvesti niti pod jednu do tada priznatu osnovu neubrojivosti. ${ }^{81}$ Ovako široko postavljeni temelji neubrojivosti u suštini pokrivaju sva moguća stanja koja mogu utjecati na intelektualne i voljne sposobnosti počinitelja, no dvojbeno je koliko udovoljavaju zahtjevu određenosti. Upitno je i opisuje li izraz teže duševne smetnje dovoljno točno i precizno stanja koja se pod njega podvode u praksi. U tom kontekstu zanimljivo je spomenuti jedan primjer iz prakse američkih sudova. Radi se o četrdesetogodišnjem učitelju koji je imao povećani interes za pornografiju koji se s vremenom preusmjerio na dječju pornografiju. Svoje aktivnosti nastojao je prikriti, znajući da je riječ o neprihvatljivom ponašanju, no nije mogao prestati jer, kako je izjavio, osjećaj ugode nadvladao je njegovu želju da se suzdrži. Nakon što je počeo pokazivati seksualne sklonosti prema svoj pokćerki, njegova supruga ga je prijavila. Dijagnosticirana mu je pedofilija i u kaznenom postupku proglašen je krivim. Sud mu je naložio da se podvrgne odgovarajućoj terapiji u rehabilitacijskom centru za seksualne ovisnike ili će ga uputiti na izdržavanje zatvorske kazne. Želeći izbjeći odlazak u zatvor, uključio se u terapiju. No, tijekom terapije nije se mogao suzdržati od seksualnih aktivnosti usmjerenih prema terapeutima i drugim osobama te je terapija prekinuta i upućen je na izdržavanje zatvorske kazne. Neposredno prije odlaska u zatvor počeo je osjećati snažne glavobolje, gubitak ravnoteže, nekontrolirano kretanje očiju i abnormalne reflekse. Tijekom neurološkog ispitivanja tražio je seksualne usluge od članica tima i nije pokazao nikakve znakove uznemirenosti nakon što se po sebi pomokrio. Nakon toga upućen je na magnetsku rezonancu koja je pokazala da ima tumor na mozgu. Nakon operacijskog zahvata kojim je tumor uklonjen, prestalo je njegovo abnormalno seksualno ponašanje kao i ostale smetnje koje je imao. Vratio se natrag kući, no nakon nekog vremena vratile su se glavobolje, kao i njegovo problematično ponašanje. Pokazalo se da se tumor vratio, pa je operacijskim zahvatom ponovo uklonjen. Sljedećih godina muškarac je bio zdrav i više nije dolazio u sukob s pravnim normama. ${ }^{82}$ Iz ovog primjera može se zaključiti da postoji određena uzročna veza između tumora na mozgu i devijantnog ponašanja. Iako tumor na mozgu izaziva česte psihičke promjene i poremećaje ponašanja, priroda tumora na mozgu i priroda psihičkih bolesti bitno se razlikuje, pa se ne čini najboljim rješenjem ovakav slučaj podvoditi pod pojam teže duševne smetnje.

81 O pojmu teže duševne smetnje više v. Goreta, M., Načelo razmjernosti u psihijatrijskoj teoriji i praksi, Medicinska naklada, Klinika za psihijatriju Vrapče, Zagreb, 2012., str. 17-25.

82 Burns, J. M., Swerdlow, R. H., Right orbitofrontal tumor with pedophilia symptom and constructional apraxia sign, Archives of Neurology, vol. 60., br. 3., 2003., str. 437-440. 


\subsection{Argumenti za i protiv ukidanja instituta neubrojivosti}

Iako je institut neubrojivosti prihvaćen u zakonodavstvima gotovo svih država, česte su rasprave o potrebi njegovog redefiniranja, a nakon stupanja na snagu Konvencije o pravima osoba s invaliditetom, sve češće se mogu čuti i zahtjevi za njegovim potpunim ukidanjem. Pritom se najčešće ističu sljedeći argumenti. ${ }^{83}$

Utvrđivanje neubrojivosti zahtijeva procjenu psihičkog stanja okrivljenika u određenom, često kratkom trenutku (tempore criminis) koji se dogodio, u pravilu, nekoliko dana, a možda i nekoliko mjeseci prije nego što se vrši procjena, što je za psihijatre, kao i za sud veliki izazov. ${ }^{84}$ Taj je problem dodatno pojačan time što postoji niz nejasnoća vezanih uz kriterije za utvrđivanje neubrojivosti. Tako definicija neubrojivosti u pojedinim državama uopće ne sadrži osnove neubrojivosti, u drugima su one usko postavljene, dok treće države sadrže toliko široke postavljene osnove da se pod njih praktički mogu podvesti sva stanja za koja se sumnja da mogu dovesti do isključenja intelektualnih i voljnih sposobnosti. Dvojbeno je i treba li definicija neubrojivosti obuhvatiti procjenu intelektualnih i voljnih sposobnosti ili je bolje rješenje procjenjivati utjecaj psihičke bolesti isključivo u odnosu na kognitivne sposobnosti okrivljenika. Naime, rasprave se vode oko uključivanja voljne komponente u definiciju neubrojivosti i mogućnosti da se pouzdano procijeni može li ili ne osoba kontrolirati svoju volju o tomu, hoće li ili ne poduzeti određenu radnju. Pri iznošenju argumenata u prilog ukidanja instituta neubrojivosti ne može se izbjeći pozivanje na profesora psihijatrije Thomasa Szasza i njegovu tvrdnju da se sva razmatranja o kaznenoj odgovornosti oslanjaju na pretpostavku da ljudi „imaju“ stanja nazvana „duševnim bolestima“ koja „uzrokuju“ činjenje kaznenih djela, a duševna bolest je zapravo mit. ${ }^{85} \mathrm{Na}$ ove nejasnoće vezane uz samu definiciju neubrojivosti, nadovezuje se sljedeći argument protiv instituta neubrojivosti koji ističe da okrivljenik može simulirati simptome određene bolesti i time izbjeći kažnjavanje. U common law sustavima kao dodatni prigovor navodi se kako je obrana neubrojivošću način kako pojedinci s visokim primanjima mogu izbjeći kaznenu odgovornost. Naime, kako je neubrojivost u ovom sustavu uvedena kao oblik obrane, optuženik je dužan pružiti dokaze da je tempore criminis bio neubrojiv. No, zbog visokih troškova svi optuženici ne raspolažu sredstvima koja bi im omogućavala najbolju obranu što doprinosi njihovu nejednakom položaju u kaznenom postupku. Konačno, bitan argument u prilog ukidanju instituta neubrojivosti njegov je stigmatizirajući karakter.

83 Ovaj dio rada u većem se dijelu temelji na argumentima koje je iznio Meynen. Meynen, G., op. cit., str. 43-62.

84 O složenosti ovakve procjene v. Packer, I. K., op. cit., str. 77.

85 Thomas Szasz, psihijatar i profesor, jedan je od najznačajnijih autora koji je smatrao da su mentalne bolesti ili bolesti mozga ili samo problemi življenja koji su rezultat svakodnevnih životnih poteškoća. Smatrajući da mnoge mentalne bolesti nisu bolesti mozga, drži da se psihijatri zapravo bave životnim problemima. Szasz, T., Ideologija i ludilo, Naprijed, Zagreb, 1980., str. 21-34. Cooper se ne slaže s tvrdnjom da je mentalna bolest mit i smatra da ni sam Szasz nije toliko radikalan kao što se čini u toj tvrdnji, budući da mentalne poremećaje koji imaju biološku osnovu smatra pravim poremećajima. Cooper, R., Psychiatry and Philosophy of Science, Acumen, Stockfield, 2007., str. 11-27. 
Naime, brojna istraživanja pokazuju da su osobe s duševnim smetnjama jedna od najstigmatiziranijih kategorija u društvu te da saznanje o tomu da osoba ima psihički poremećaj često dovodi do marginaliziranja, izbjegavanja, omalovažavanja, prijezira i podcjenjivanja te osobe. Kada takva osoba dođe u sukob s normama kaznenog prava, stigma duševnog bolesnika koji je opasnost za sigurnost drugih ljudi postaje master status te osobe. Negativan master status neizostavan je kod neubrojivih osoba. One se u pravilu identificiraju samo kroz jedan sloj svoga identiteta - onoga da su duševno bolesne i opasne. U tom slučaju predrasude koje se povezuju s postojanjem psihičke bolesti kao izgovorom za negiranje odgovornosti dodatno stigmatiziraju ove osobe. Položaj neubrojivih počinitelja možda je najbolje opisao Sarkar navodeći kako ove osobe pate od dvostruke stigme: da su ludi i loši. ${ }^{86}$

Vezano uz navedene prigovore koji se odnose na poteškoće vezane uz definiranje i utvrđivanje neubrojivosti, možemo se složiti sa zaključkom da sud ima iznimno složenu zadaću pri utvrđivanju neubrojivosti. No, ne treba izgubiti iz vida da i dokazivanje nekih drugih instituta u kaznenom pravu, primjerice, namjere, također nameće slične izazove pred sud. Mogućnost simuliranja duševne bolesti koja se ističe kao argument u prilog ukidanja neubrojivosti, također se ne može negirati. Psihijatri, kao i sud, svjesni su takvog rizika i posebno su usmjereni na otkrivanje znakova koji upućuju na simuliranje bolesti. Pored toga, simuliranje ili lažno iskazivanje pred sudom nije ograničeno samo na institut neubrojivosti. Sudovi su često suočeni sa slučajevima u kojima se osobe pozivaju na amneziju pri svjedočenju kako bi okrivljenik izbjegao odgovornost za počinjeno djelo. U odnosu na prilično radikalan stav profesora Szasza o duševnoj bolesti kao mitu, mora se reći da i danas postoje rasprave i različita shvaćanja o tomu kako definirati pojam duševne bolesti, ${ }^{87}$ pa je posve na mjestu pitanje o tomu koje implikacije to ima na institut neubrojivosti. Ono što se sa sigurnošću može reći jest da zasigurno ne doprinosi njegovu boljem razumijevanju. Meynen ispravno zaključuje kako bi jednoznačno pojmovno objašnjenje mentalnog

86 Sarkar, S. P., Legal models and treatment approaches for the MDO: United States of America, u: Bartlett, A., McGauley (ur.), Forensic mental health. Concepts, systems and practice, Oxford University Press, Oxford, 2010., str. 405.

87 Bez ulaženja u dublju diskusiju valja istaknuti nekoliko pravaca u suvremenim raspravama oko ovog pojma. S jedne strane, mentalne bolesti definiraju se kao lezije na mozgu ili psihopatološke promjene. Polazi se od toga da se nešto smatra mentalnom bolešću samo ako su simptomi te bolesti rezultat određenih promjena na mozgu, pri čemu takve promjene ne moraju biti odmah vidljive. Sve dok se razumno pretpostavlja da su lezije mozga prisutne, konstelacija znakova i simptoma opravdano se može razmatrati kao duševna bolest. Ovaj je model problematičan iz više razloga od kojih treba istaknuti oskudno znanje o psihopatološkim promjenama na mozgu, kao i da se zbog samih promjena na mozgu ne može pretpostaviti postojanje duševne bolesti. S druge strane, imamo one koji smatraju da psihičku bolest treba definirati kao breakdown of meaning. Duševna bolest obuhvaćala bi stanja ili uvjete koje karakterizira gubitak značenja u smislu da stvari koje osoba govori ili radi nemaju smisla. U svakodnevnom životu često se poseže upravo za takvim tumačenjem duševne bolesti. Ako se osoba ponaša neuobičajeno ili počini ozbiljan zločin koji se ne može objasniti i koji je bez vidljivog motiva, bit će upućena u psihijatrijsku ustanovu. Drugim riječima, dok god možemo shvatiti zašto se netko ponaša na određeni način, čak i ako se ne slažemo s time, neće biti riječ o poremećaju. No, i ovakvo poimanje duševne bolesti ima ozbiljne nedostatke jer se suviše oslanja na subjektivne kriterije. Meynen, G., op. cit., str. 53-54. 
poremećaja zacijelo bilo korisno, no ne možemo tvrditi da zbog njegova izostanka ne postoji osnova za neubrojivost. ${ }^{88}$

\section{ZAKLJUČAK}

Utjecaj Konvencije o pravima osoba s invaliditetom na kaznenopravni institut neubrojivosti valja razmotriti kroz dvije razine. Prva se odnosi na zahtjev da se odredba članka 12. koja uvodi bitne novine u području priznavanja poslovne sposobnosti osoba s duševnim smetnjama proširi i na područje njihove kaznene odgovornosti. Druga razina odnosi se na razmatranje opravdanosti zahtjeva za redefiniranjem ili ukidanjem instituta neubrojivosti i uvođenjem novih rješenja koja se neće pozivati na postojanje duševnih bolesti ili poremećaja.

Prihvaćanje stava pojedinih autora koji smatraju, pozivajući se na članak 12. i njegovo tumačenje od strane Odbora, kako se mentalne sposobnosti osobe ne smiju uzimati u obzir pri razmatranju njezine kaznene odgovornosti, značilo bi napuštanje nekih od temeljnih načela svih suvremenih kaznenopravnih sustava i vraćanje nekoliko stoljeća unazad. Stoga se ovako radikalna interpretacija članka 12. i njezino nekritično prihvaćanje u području kaznenog prava ne može prihvatiti. No, to ne znači da su sve kritike na račun kaznenopravnog položaja osoba s duševnim smetnjama bez osnove i da nema mjesta za napredak.

Nakon stupanja na snagu Konvencije, sve češće se mogu čuti zahtjevi za ukidanjem instituta neubrojivosti uz obrazloženje kako negiranje kaznene odgovornosti zbog neubrojivosti predstavlja diskriminaciju osoba s psihosocijalnim i intelektualnim oštećenjima, krši pravo na jednakost pred zakonom te produbljuje njihovu stigmatizaciju u društvu. Ovi prigovori nisu bez osnove i valja ih pažljivo razmotriti. Izravno povezivanje bilo koje psihijatrijske dijagnoze s ekskulpacijom od kaznene odgovornosti upućuje na pogrešan zaključak kako osobe s takvom dijagnozom općenito nisu sposobne donositi odluke i negira njihovu autonomiju. Stoga je izdvajanje osoba s duševnim smetnjama u zasebnu skupinu za koju vrijede posebna pravila, samo na temelju postojanja dijagnoze diskriminirajuće i kao takvo neprihvatljivo. Pored toga, niz znanstvenih istraživanja potvrđuje da je jedan od najvećih problema s kojim se suočavaju osobe s duševnim smetnjama njihova stigmatizacija. U svim društvima, neovisno o stupnju njihovog razvoja, samo spominjanje dijagnoze psihičke bolesti ima dalekosežne stigmatizirajuće učinke. No, istodobno, psihičko zdravlje pojedinca izravno utječe na njegovu krivnju u kaznenom pravu i ne može se ignorirati. Neprihvatljivo bi bilo nametanje kaznene odgovornosti osobama koje nemaju pravilnu predodžbu o prirodnom i društvenom značenju svog djela kao nedopuštenom činu, koje nisu svjesne uzročne veze između svoje radnje i prouzročene posljedice te ne mogu vladati svojim fizičkim radnjama.

S obzirom na navedeno nameće se pitanje, mogu li se iz kaznenog prava izbaciti instituti koji u svojim definicijama izravno sadrže pozivanje na duševne bolesti i poremećaje, a da se pritom ne naruše njegovi temeljni postulati. Primjeri pojedinih stranih zakonodavstava, iako rijetki, pokazuju kako je moguć pozitivan odgovor 
na ovo pitanje. Tako su četiri američke države napustile obranu neubrojivošću kao zasebnu obranu, pronašavši u okviru mens rea alternativna rješenja za okrivljenike s duševnim smetnjama koji krše pravne norme, a nisu sposobni za krivnju. No, treba istaknuti kako i u pravu ovih država, mentalne sposobnosti osobe i dalje imaju ulogu prilikom donošenja odluka, samo što se one ne procjenjuje u okviru zasebno reguliranog instituta neubrojivosti, već u okviru nekih drugih subjektivnih elemenata kaznenog djela. Teoretski bi ovakvo rješenje bilo moguće provesti i u drugim državama $\mathrm{i}$ to na način da postojeći kaznenopravni instituti (ponajprije instituti namjere, nehaja i zabluda) preuzmu ulogu koju sada ima neubrojivost. No, treba izričito naglasiti da za razliku od anglosaksonske doktrine koja ne posvećuje preveliku pažnju kaznenom materijalnom pravu, zemlje kontinentalnoga pravnog kruga imaju detaljno razrađenu kaznenopravnu dogmatiku, pa s prijedlozima koji vode ukidanju nekih od temeljenih kaznenopravnih instituta, kao što je institut neubrojivosti, valja biti krajnje oprezan. Stoga je prihvatljivije drugo rješenje koje uključuje razmatranje mogućnosti redefiniranja pojma neubrojivosti na način da se iz definicije neubrojivosti ispusti navođenje biopsiholoških osnova. Time bi se izbjeglo izdvajanje pojedinih psihijatrijskih dijagnoza i prejudiciranje njihove pravne relevantnosti za pojedino pravno pitanje. ${ }^{89}$ Definicija neubrojivosti u švicarskom Kaznenom zakonu koja se temelji isključivo na procjeni intelektualnih i voljnih sposobnosti počinitelja i obuhvaća sve situacije koje za potencijalnu posljedicu mogu imati nesposobnost osobe da shvati značenje svog postupanja i vlada svojom voljom, bez obzira na njihov uzrok pokazuje nam da ovakvo rješenje nije u praksi potpuno nepoznato. Čineći definiciju neubrojivosti neutralnom izbacivanjem kriterija psihičkih bolesti otklonio bi se jedan segment diskriminacije osoba s duševnim smetnjama i barem donekle ublažili problemi njihove stigmatizacije u društvu.

\section{LITERATURA}

Knjige i članci:

1. Amer, A. B., Informed Consent and Adult Psychiatry, Oman Medical Journal, vol. 28., br. 4., 2013., str. 228-231.

2. Arnardóttir, O. M.; Quinn, G., The UN Convention on the Rights of Persons with Disabilities, European and Scandinavian Perspectives, Martinus Nijhoff Publishers, Netherlands, 2009.

3. Bach, M., The right to legal capacity under the UN Convention on the Rights of Persons with Disabilities: Key concepts and directions from law reform, Institute for Research and Development on Inclusion and Society (IRIS), Toronto, 2009.

4. Barlett, P., The United Nations Convention on the Rights of Persons with Disabilities and Mental Health Law, Modern Law Review, vol. 75., br. 5., 2012., str. 752-778.

5. Banner, N. F.; Szmukler, G., ,, Radical interpretation “ and the Assessment of decisionmaking capacity, Journal of Applied Philosophy, vol. 30., br. 4., 2013., str. 379-394.

6. Burns, J. M., Swerdlow, R. H., Right orbitofrontal tumor with pedophilia symptom and constructional apraxia sign, Archives of Neurology, vol. 60., br. 3., 2003., str. 437-440.

7. Caivano, N., Conceptualizing Capacity: Interpreting Canada's Qualified Ratification of

89 Škorić, M.; Srdoč, E., Pravni položaj neubrojivih počinitelja protupravnih djela u Republici Hrvatskoj, Zbornik Pravnog fakulteta Sveučilišta u Splitu, god. 52., br. 4., 2015., str. 935. 
Article 12 of the UN Disability Rights Convention, Western Journal of Legal Studies, vol. 4, br. 1., 2014., str. 1-23.

8. Callaghan, S. M.; Ryan C., Is there a future for involuntary treatment in Right-based Mental Health Law, Psychiatry, Psychology and Law, vol. 21., br. 5., 2014., str. 747766.

9. Callaghan, S. M.; Ryan C., An evolving revolution: Evaluating Australia's compliance with the Convention on the Rights of Persons with Disabilities in Mental Health Law, UNSW Law Journal, vol. 39., br. 2., 2016., str. 596-624.

10. Carlan, P.; Nored, L. S.; Downey, R. A., An Introduction to Criminal Law, Jones and Bartlett Publishers, Inc, United States, 2001.

11. Cooper, D., And You Can't Find Me Nowhere: Relocation Identity and Structure within Equality Jurisprudence, Journal of Law and Society, vol. 27., br. 2., 2000., str. 249-272.

12. Cooper, R., Psychiatry and Philosophy of Science, Stockfield, Acumen, 2007.

13. Craigie, J., A Fine Balance: Reconsidering Patient Autonomy in Light of the UN Convention on the Rights of Persons with Disabilities, Bioethics, vol. 29., br. 6., 2015., str. 398-405.

14. Dawson, J., A realistic approach to assessing mental health laws' compliance with the UNCRPD, International Journal of Law and Psychiatry, vol. 40., 2015., str. 70-79.

15. Dworkin, R., Sovereign Virtue, the Theory and Practice of Equality, Cambridge, MA, Harvard University Press, 2000.

16. Đurđević, Z., Pravni položaj počinitelja kaznenih djela s duševnim smetnjama, Hrvatsko udruženje za kaznene znanosti i praksu, Zagreb, 2002.

17. Flynn, E.; Arstein-Kerslake, A., The Support Model of Legal Capacity: Fact, Fiction, or Fantasy?, Berkley Journal of International Law, vol. 23., br. 1., 2014., str. 124-143.

18. Goreta, M., Načelo razmjernosti u psihijatrijskoj teoriji i praksi, Medicinska naklada, Klinika za psihijatriju Vrapče, Zagreb, 2012., str. 17-25.

19. Graf, M.; Dittmann, V., Psychopathic Disorder and the Criminal Law in Switzerland, u: Felthous, A., Sass, H. (ur.), International Handbook on Psychopathic Disorders and the Law, volume II, John Wiley and Sons, Ltd., Chichester, West Sussex, 2008.

20. Greer, S., The European Convention on Human Rights. Achievements, Problems and Prospects. Cambridge Studies in European Law and Policy, Cambridge, Cambridge University Press, 2006.

21. Grozdanić, V. (ur.), Komentar Zakona o zaštiti osoba s duševnim smetnjama, Pravni fakultet Sveučilišta u Rijeci, Rijeka, 2015.

22. Grozdanić, V., Tragovi razvoja posebnog statusa neuračunljivog delinkventa u povijesti krivičnog prava starog $i$ srednjeg vijeka, Zbornik Pravnog fakulteta u Rijeci, god. 9., 1988., str. 37-52.

23. Grozdanić, V.; Škorić, M.; Martinović, I., Kazneno pravo, opći dio, Pravni fakultet Sveučilišta u Rijeci, Rijeka, 2013.

24. Gröning, L.; Rieber-Mohn, G. F., NOU 2014:10 - Proposal for New Rules Regarding Criminal Insanity and Related Issues, Norway post-22 July, Bergen Journal of Criminal Law and Criminal Justice, vol. 3., br. 1., 2015., str. 109-131.

25. Hörnle, T., Guilt and Choice in Criminal Law Theory - A Critical Assessment, Bergen Journal of Criminal Law and Criminal Justice, vol. 4., br. 1., 2016., str. 1-24.

26. Jacobsen, J.; Hallgren Sandvik, V., An Outline of the New Norwegian Criminal Code, Bergen Journal of Criminal Law and Criminal Justice, vol. 3., br. 2., 2015., str. 162-183.

27. Kayess, R.; French, P., Out of darkness into light? Introducing the Convention on the Rights of Persons with disabilities, Human Rights Law Review, vol. 8., br. 1., 2008., str. 1-34.

28. Lanham, D., Larsonneur Revisited, Criminal Law Review, 1976.

29. Matthews, S., Failed agency and the insanity defence, International Journal of Law and Psychiatry, vol. 27., br. 5., 2004., str. 413-424. 
30. Meynen, G., Legal Insanity: Explorations in Psychiatry, Law, and Ethics, Springer, 2016.

31. Minkowitz, T., Rethinking criminal responsibility from a critical disability perspective: The abolition of insanity/incapacity acquittals and unfitness to plead, and beyond, Griffith Law Review, vol. 23., br. 3., 2014., str. 434-466.

32. Minkowitz, T., Submission to Committee on the Rights of Persons with Disabilities on the Draft General Comment on Article 12, January 22, 2014.

33. Minkowitz, T., The United Nations Convention on the Rights of Persons with Disabilities and the right to be free from non-consensual psychiatric interventions, Syracuse Journal of International Law and Commerce, vol. 34., br. 2., 2007., str. 405-428.

34. Morse, S. J., Mental disorder and criminal law, Journal of Criminal Law and Criminology, vol. 101., br. 3., 2011., str. 885-968.

35. Novoselec, P., Opći dio kaznenog prava, Pravni fakultet, Osijek, 2016.

36. Omejec, J., Konvencija za zaštitu ljudskih prava i temeljnih sloboda u praksi Europskog suda za ljudska prava, Strasbourški acquis, Novi informator, Zagreb, 2013.

37. Packer, I. K., Evaluation of criminal responsibility, Oxford University Press, Oxford, 2009.

38. Parmigiani, G.; Mandarelly, G.; Meynen, G. et al., Free will, neuroscience, and choice: towards a decisional capacity model for insanity defense evaluations, Rivista di psichiatria, vol. 52., br. 1., 2017., str. 9-15.

39. Phillips, A., Which Equalities Matter?, Malden, Blackwell, 1999.

40. Sarkar, S. P., Legal models and treatment approaches for the MDO: United States of America, u: Bartlett, A., McGauley (ur.), Forensic mental health. Concepts, systems and practice, Oxford University Press, Oxford, 2010.

41. Schulze, M., Understanding The UN Convention On The Rights Of Persons with Disabilities, A Handbook on the Human Rights of Persons with Disabilities, Handicap International, September, 2009.

42. Slobogin, C., Eliminating mental disability as a legal criterion in deprivation of liberty cases: the impact of the Convention on the rights of persons with disabilities on the insanity defense, civil commitment, and competency law, International Journal of Law and Psychiatry, vol. 40., 2015., str. 36-42.

43. Stratenwerth, G.; Wohlers, W., Schweizerisches Strafgesetzbuch, Handkommentar, Stämpfli Verlag, Bern, 2013.

44. Szasz, T., Ideologija i ludilo, Naprijed, Zagreb, 1980.

45. Škorić, M.; Srdoč, E., Pravni položaj neubrojivih počinitelja protupravnih djela $u$ Republici Hrvatskoj, Zbornik Pravnog fakulteta Sveučilišta u Splitu, god. 52., br. 4., 2015., str. 933-953.

46. Štrkalj Ivezić, S., Procjena kapaciteta za odlučivanje kao ključan faktor u donošenju odluke za lišavanje poslovne sposobnosti, u: Poslovna sposobnost i skrbništvo raskorak između Konvencije o pravima osoba s invaliditetom i prakse, Zbornik radova sa stručnog skupa, Pravobraniteljica za osobe s invaliditetom, Zagreb, 2012., str. 65-74.

47. Vincent, N. A., Responsibility, Dysfunction and Capacity, Neuroethics, vol. 1., br. 3., 2008., str. 199-204.

Ostali izvori:

1. Konvencija o pravima osoba s invaliditetom, Narodne novine - Međunarodni ugovori, 6/2007., 5/2008.

2. Committee on the Rights of Persons with Disabilities, General comment No. 1 (2014), Article 12: Equal recognition before the law, CRPD/C/GC/1, 19 May 2014.

3. Report of the Special Rapporteur on the right of everyone to the enjoyment of the highest attainable standard of physical and mental health, Paul Hunt, Report to the Sixty-first 
session of the Commission on Human Rights, 11 February 2005, E/CN.4/2005/51

4. UN High Commissioner for Human Rights, Annual Report, Thematic Study on CRPD, A/HRC/10/48, 26 January 2009.

5. Annual report of the United Nations High Commissioner for human rights and Reports of the Office of the High Commissioner and the Secretary-General, Thematic Study by the Office of the United Nations High Commissioner for Human Rights on enhancing awareness and understanding of the Convention on the Rights of Persons with Disabilities, A/HRC/10/48, 26 January 2009.

6. Commissioner for Human Rights, Who gets to decide?, Rights to legal capacity for persons with intellectual and psychosocial disabilities, Council of Europe, Strasbourg, 20 February 2012., CommDH/IssuePaper(2012)2. 


\section{Marissabell Škorić*}

Summary

\section{THE INFLUENCE OF THE CONVENTION ON THE RIGHTS OF PERSONS WITH DISABILITIES UPON THE CRIMINAL LAW'S CONCEPTION OF INSANITY}

The paper analyses the influence of the Convention on the Rights of Persons with Disabilities upon the criminal status of one group of persons with disabilities, hence, persons suffering from mental disorders. Although there is no explicit mention of criminal responsibility in the Convention, some interpretations suggest that the provisions of the Convention request abolition of some criminal law mechanisms which would apply if the person accused of a crime suffered from a mental disorder. These mechanisms, as suggested by those interpretations, are contrary to the Convention's provisions, in particular to articles 5 and 12.

This paper thus examines whether article 12, which introduces significant novelties into the recognition of legal capacity for persons suffering from mental disorders, may also be extended to the criminal responsibility of those persons. Furthermore, the paper investigates whether the definition of insanity, based on the definition of mental disorders, is contrary to the requests of the Convention, especially to the provisions of article 5 on equality and non-discrimination.

Keywords: Convention on the Rights of Persons with Disabilities, insanity, prohibition of discrimination.

Zussamenfassung

\section{EINFLUSS DES ÜBEREINKOMMENS ÜBER DIE RECHTE VON MENSCHEN MIT BEHINDERUNGEN AUF DAS RECHTSINSTITUT DER SCHULDUNFÄHIGKEIT}

Die Arbeit analysiert den Einfluss des Übereinkommens über die Rechte von Menschen mit Behinderungen auf die strafrechtliche Lage der Personen mit seelischen Störungen. Obwohl der Begriff der strafrechtlichen Verantwortung im Übereinkommen nicht ausdrücklich erwähnt wird, weisen manche Auslegungen des Übereinkommens darauf hin, dass dessen Bestimmungen die Abschaffung mancher

* Marissabell Škorić, Ph. D., Associate Professor, Faculty of Law, University of Rijeka; skoric@ pravri.hr 
Strafrechtsinstitute, welche bei den Beschuldigten mit psychischen Störungen angewendet werden können, erfordern, weil diese Rechtsinstitute nicht im Einklang mit den Bestimmungen des Übereinkommens sind, insbesondere mit Artikel 5 und 12.

Ziel dieser Arbeit ist es, zu untersuchen, ob die Bestimmung des Art. 12, welche im Bereich der Anerkennung der Geschäftsfähigkeit von Personen mit seelischen Störungen wesentliche Neuigkeiten einführt, auch aufden Bereich ihrer strafrechtlichen Verantwortung erweitert werden kann. Ebenfalls wird erforscht, ob die auf den Begriff der seelischen Störung beruhende Definition der Schuldunfähigkeit im Widerspruch zu den Forderungen des Übereinkommens, insbesondere zur Bestimmung des Art. 5 über die Gleichberechtigung und Nichtdiskriminierung, steht.

Schlüsselwörter: Übereinkommen über die Rechte von Menschen mit Behinderungen, Personen mit seelischen Störungen, Schuldunfähigkeit, Verbot der Diskriminierung.

Riassunto

\section{L'INFLUENZA DELLA CONVENZIONE SUI DIRITTI DELLE PERSONE CON DISABILITÀ SULL'ISTITUTO GIURIDICO PENALE DELL'IMPUTABILITÀ}

Nello scritto si analizza l'influenza della Convenzione sui diritti delle persone con disabilità sulla posizione giuridica penale di un gruppo di persone con disabilità, e cioè le persone affette da disturbi mentali. Benché nella Convenzione non si faccia espresso riferimento alla responsabilità penale, esistono interpretazioni secondo le quali le disposizioni della Convenzione imporrebbero l'abrogazione degli istituti giuridici penali la cui applicazione sia fondata sull'esistenza di disturbi psichici in capo all'imputato, in quanto contrarie alle norme della Convenzione, in ispecie agli artt. 5 e 12.

Lo scopo di questo scritto è di indagare se la norma dell'art. 12, che introduce rilevanti novità nel campo del riconoscimento della capacità di agire in capo alle persone affette da disturbi mentali possa estendersi anche al campo della loro responsabilità penale e per l'effetto interrogarsi se la definizione di incapacità di intendere e volere che si basa sui disturbi mentali sia contraria alle richieste della Convenzione, in ispecie all'art. 5 sull'eguaglianza e la non discriminazione.

Parole chiave: Convenzione sui diritti delle persone con disabilità, persone con disturbi mentali, incapacità di intendere e volere, divieto di discriminazione. 
